\title{
On the link between hygroscopicity, volatility, and oxidation state of ambient and water-soluble aerosols in the southeastern United States
}

\author{
K. M. Cerully ${ }^{1, \text { a }}$, A. Bougiatioti ${ }^{2,3}$, J. R. Hite $\mathrm{Jr}^{2}{ }^{2}$ H. Guo ${ }^{2}$, L. Xu ${ }^{1}$, N. L. Ng ${ }^{1,2}$, R. Weber ${ }^{2}$, and A. Nenes ${ }^{1,2,4}$ \\ ${ }^{1}$ School of Chemical and Biomolecular Engineering, Georgia Institute of Technology, Atlanta, GA, USA \\ ${ }^{2}$ School of Earth and Atmospheric Sciences, Georgia Institute of Technology, Atlanta, GA, USA \\ ${ }^{3}$ Laser Remote Sensing Laboratory, National Technical University of Athens, Zografou, Greece \\ ${ }^{4}$ Institute of Chemical Engineering Sciences, Foundation for Research and Technology, Hellas, Patras, Greece \\ ${ }^{a}$ now at: TSI, Inc., Shoreview, MN, USA
}

Correspondence to: A. Nenes (athanasios.nenes@gatech.edu)

Received: 18 September 2014 - Published in Atmos. Chem. Phys. Discuss.: 9 December 2014

Revised: 18 May 2015 - Accepted: 22 June 2015 - Published: 7 August 2015

\begin{abstract}
The formation of secondary organic aerosols (SOAs) combined with the partitioning of semivolatile organic components can impact numerous aerosol properties including cloud condensation nuclei (CCN) activity, hygroscopicity, and volatility. During the summer 2013 Southern Oxidant and Aerosol Study (SOAS) field campaign in a rural site in the southeastern United States, a suite of instruments including a CCN counter, a thermodenuder (TD), and a high-resolution time-of-flight aerosol mass spectrometer (AMS) were used to measure $\mathrm{CCN}$ activity, aerosol volatility, composition, and oxidation state. Particles were either sampled directly from ambient or through a particleinto-liquid sampler (PILS), allowing the investigation of the water-soluble aerosol component. Ambient aerosols exhibited size-dependent composition with larger particles being more hygroscopic. The hygroscopicity of thermally denuded aerosols was similar between ambient and PILS-generated aerosols and showed limited dependence on volatilization. Results of AMS three-factor positive matrix factorization (PMF) analysis for the PILS-generated aerosols showed that the most hygroscopic components are most likely the most and the least volatile features of the aerosols. No clear relationship was found between organic hygroscopicity and the oxygen-to-carbon ratio; in fact, isoprene-derived organic aerosols (isoprene-OAs) were found to be the most hygroscopic factor, while at the same time being the least oxidized and likely most volatile of all PMF factors. Considering the diurnal variation of each PMF factor and its asso-
\end{abstract}

ciated hygroscopicity, isoprene-OA and more-oxidized oxygenated organic aerosols are the prime contributors to hygroscopicity and co-vary with less-oxidized oxygenated organic aerosols in a way that induces the observed diurnal invariance in total organic hygroscopicity. Biomass burning organic aerosols contributed little to aerosol hygroscopicity, which is expected since there was little biomass burning activity during the sampling period examined.

\section{Introduction}

Aerosols are well known to be important drivers of climate from regional to global scales by serving as cloud condensation nuclei $(\mathrm{CCN})$ and scattering and absorbing radiation (IPCC, 2007, 2013). Though much progress has been made in understanding the role of aerosols in the climate system, the formation of secondary organic aerosols (SOAs) and the partitioning of semivolatile organics are topics subject to considerable uncertainty (e.g., Kanakidou et al., 2005; Goldstein and Galbally, 2007; Kroll and Seinfeld, 2008; Donahue et al., 2009; Hallquist et al., 2009; Ervens et al., 2011). Recent studies show that different estimation methods of SOA production result in ranges from 140 to $910 \mathrm{Tg} \mathrm{C} \mathrm{yr}^{-1}$ (Goldstein and Galbally, 2007). The large uncertainty in these estimates (e.g., Pye and Seinfeld, 2010; Hallquist et al., 2009; Jimenez et al., 2009; Kanakidou et al., 2005) illustrates the 
need for better understanding of organic aerosol composition, volatility, hygroscopicity, and CCN activity.

Few studies have investigated the link between aerosol hygroscopicity, volatility, and level of aerosol oxidation (e.g., Jimenez et al., 2009; Poulain et al., 2010; Tritscher et al., 2011; Hong et al., 2014), though numerous studies have focused on the link between two of these parameters (e.g., Kuwata et al., 2007; Asa-Awuku et al., 2009; Meyer et al., 2009; Ristovski et al., 2010; Massoli et al., 2010; Chang et al., 2010; Lambe et al., 2011; Lathem et al., 2013; Frosch et al., 2011, 2013; Villani et al., 2013; Xu et al., 2014). Several studies have shown and proposed parameterizations for the relationship between organic hygroscopicity and degree of oxidation (e.g., Chang et al., 2010; Massoli et al., 2010; Lambe et al., 2011; Duplissy et al., 2011; Frosch et al., 2013), with the hygroscopicity parameter, $\kappa$, being either inferred from subsaturated growth factor (GF) measurements or supersaturated CCN activation spectra (Petters and Kreidenweis, 2007) and the degree of oxidation represented by the oxygen-to-carbon ratio $(\mathrm{O}: \mathrm{C})$ or $f_{44}$, the ratio of the $m / z 44$ peak to the total organics signal in an aerosol mass spectrometer (AMS) (Ng et al., 2010; Aiken et al., 2008). Jimenez et al. (2009) showed results of several studies correlating GF with $\mathrm{O}: \mathrm{C}$ and proposed a 2-dimensional framework for organic aerosols where hygroscopicity and oxidation level increase with decreasing volatility. There are several other studies, though, that have shown that the link between these properties is not always straightforward (e.g., Meyer et al., 2009; Poulain et al., 2010; Frosch et al., 2011; Tritscher et al., 2011; Lathem et al., 2013; Alfarra et al., 2013; Villani et al., 2013). Frosch et al. (2011) saw weak sensitivity of supersaturated $\kappa$ to $\mathrm{O}: \mathrm{C}$ and $f_{44}$, respectively; Alfarra et al. (2013) saw weak correlation for both subsaturated and supersaturated hygroscopicity measurements with $f_{44}$ in laboratory studies of $\alpha$-pinene SOA. Tritscher et al. (2011) found in chamber studies of $\alpha$-pinene SOA that volatility generally decreased while subsaturated hygroscopicity and $\mathrm{O}: \mathrm{C}$ remained fairly constant, and an additional study of $\alpha$-pinene SOA by Meyer et al. (2009) measured a decrease in subsaturated hygroscopicity with increased volatility. Lathem et al. (2013) found that for biomass burning aerosols sampled during the ARCTAS and ARCPAC field campaigns, supersaturated organic hygroscopicity increased while $\mathrm{O}: \mathrm{C}$ remained fairly constant. In ambient measurements by Villani et al. (2013), subsaturated hygroscopicity in several externally mixed air masses was found to both increase or decrease after volatilization. Asa-Awuku et al. (2009) observed that the most hygroscopic fraction of $\beta$-caryophyllene SOA was also the most volatile. Kuwata et al. (2007) found for subsaturated measurements of ambient aerosols in Tokyo that, after briefly heating to $400^{\circ} \mathrm{C}$, a less hygroscopic particle mode was also less volatile while a more hygroscopic mode was more volatile. The results of these studies illustrate the range of possible relationships between hygroscopicity, volatility, and oxidation level and the need to better under- stand why and when these interactions occur. An additional level of complexity arises in interpreting these results as subsaturated GF and supersaturated $\kappa$ measurements can differ due to the difference in water volume between measurement conditions, thus impacting the assumption of an ideal solution and the importance of surface tension effects and partial solubility (Wex et al., 2009; Petters et al., 2009; Ruehl et al., 2010). Furthermore, recent studies have shown that average carbon oxidation state, $\overline{\mathrm{OS}}_{\mathrm{c}}$, may be a better indicator of aerosol oxidation than $\mathrm{O}: \mathrm{C}$ as $\mathrm{O}: \mathrm{C}$ may not capture oxidative changes due to the breaking and forming of bonds (Kroll et al., 2009, 2011).

Also important to SOA formation and processing are aqueous phase aerosols. Aqueous particles can both absorb species from the gas phase and serve as a medium for aqueous SOA production (e.g., Zuend and Seinfeld, 2012; Ervens et al., 2011, 2013; Sareen et al., 2010). Hennigan et al. (2009) found that water-soluble organic carbon represented a major portion of SOA in Atlanta. It has been proposed that SOA produced in the aqueous phase may have higher $\kappa$ than SOA formed in the gas phase with an upper limit comparable to ammonium sulfate $(\kappa=0.6)$ (Ervens et al., 2011); few experiments, however, have quantified the impact of SOA aqueous phase processes on total $\kappa$ in ambient aerosols.

The southeastern United States presents itself as a particularly interesting location of study, as it has experienced an overall cooling trend in surface temperature (1950-2006 average; Portmann et al., 2009) in contrast to the largely warming trend seen elsewhere in the United States. Carlton and Turpin (2013) found that aqueous SOA formation is particularly important in the eastern United States. These findings demonstrate that the SOA processes happening in this region are both complex and important. Motivated by these findings, the Southern Oxidant and Aerosol Study (SOAS) was a collaborative field mission which aimed to study the aerosols in the region. This study focuses on aerosols collected at a rural field site in Centreville, Alabama, and uses a variety of aerosol instrumentation to probe aerosol composition, volatility, and $\mathrm{CCN}$ properties.

\section{Data collection}

\subsection{Measurement site}

Data were collected during the Southern Oxidant and Aerosol Study (http://soas2013.rutgers.edu), part of the Southeast Atmosphere Study (SAS; http://www.eol.ucar.edu/ projects/sas), in Centreville, Alabama $\left(+32^{\circ} 54^{\prime} 11.81^{\prime \prime} \mathrm{N}\right.$, $87^{\circ} 14^{\prime} 59^{\prime \prime} \mathrm{W}$ ), a site highly influenced by biogenic volatile organic compound emissions combined with varying levels of anthropogenic influence (http://soas2013.rutgers. edu/). Measurements were taken from 1 June through 15 July 2013 using a suite of aerosol instrumentation, including a Droplet Measurement Technologies continuous-flow 


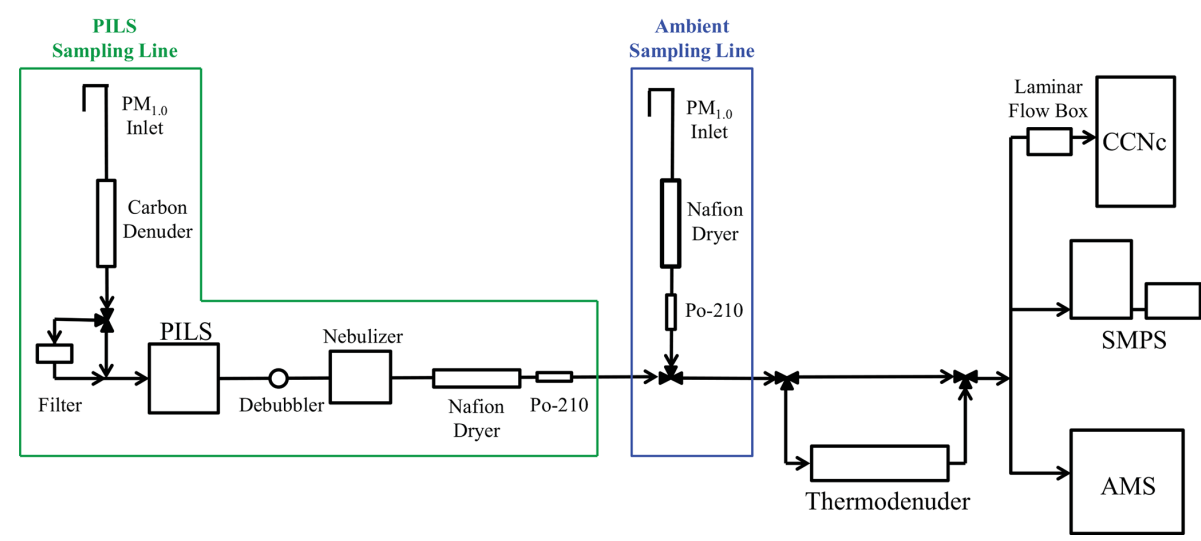

Figure 1. Instrument setup used during the SOAS campaign, combining a PILS, thermodenuder, CCNc, AMS, and SMPS to measure the water-soluble fraction of ambient aerosol (green line) and ambient aerosol (blue line).

streamwise thermal gradient CCN counter (referred to hereafter as the CCNc; Roberts and Nenes, 2005; Lance et al., 2006), thermodenuder (TD; Cerully et al., 2014), particleinto-liquid sampler (PILS; Weber et al., 2001; Orsini et al., 2003), and high-resolution time-of-flight aerosol mass spectrometer (HR-ToF-AMS, referred to hereafter as AMS; DeCarlo et al., 2006) to quantify CCN activity and hygroscopicity, volatility, water-soluble aerosol components, and aerosol composition and oxidation state, respectively. These measurements are then used here to investigate the relationship between hygroscopicity, volatility, and oxidation state for the ambient and water-soluble fraction of the aerosols sampled.

\subsection{Experimental setup and data collection}

The instrument setup is shown in Fig. 1. Aerosols were collected using a $\mathrm{PM}_{1.0}$ cyclone and either directly introduced into the aerosol instrumentation or passed through the PILS to study the water-soluble fraction of the aerosol (as the aerosol is not dried before entering the PILS, any volatile aqueous phase material is also captured). The former flow configuration is hereon called "ambient aerosol", while the latter is referred to as "PILS aerosol". Prior to analysis, ambient aerosol is first dried using a Nafion dryer and charge-neutralized using a Po-210 bipolar charging source. The PILS liquid is then filtered ( $25 \mathrm{~mm}$ diameter, $0.45 \mu \mathrm{m}$ pore syringe filter, Fisher Scientific, Fisherbrand*), passed through a debubbler, nebulized (U-5000AT, Cetac Technologies Inc., Omaha, Nebraska, USA; Ohata et al., 2011), dried with a Nafion dryer, and charge-neutralized. The polydisperse aerosol stream then passed through the TD or through a bypass line before being sampled by the AMS, scanning mobility particle sizer (SMPS; TSI Classifier model 3080, condensation particle counter (CPC) model 3022A), and CCNc. To account for nebulizer efficiency and any losses in the PILS-nebulizer system, sulfate measured by the PILS-AMS system was compared to ambient AMS sulfate and used as a scaling factor. Sulfate is used for this pur- pose because it is completely water soluble and nonvolatile. The CCNc was operated in Scanning Flow CCN Analysis (SFCA) mode (Moore and Nenes, 2009), scanning flow rate sinusoidally from 0.2 to $0.9 \mathrm{~L} \mathrm{~min}^{-1}$ then back to $0.2 \mathrm{~L} \mathrm{~min}^{-1}$ over $2 \mathrm{~min}$, resulting in a $\mathrm{CCN}$ spectrum between 0.10 and $0.40 \%$ supersaturation, $s$ (see Sect. 3.1). The flow entering the $\mathrm{CCNc}$ was held constant at $1 \mathrm{Lmin}^{-1}$ using a laminar flow box and introduced to the CCN column as needed. The sheath-to-aerosol ratio in the $\mathrm{CCNc}$ was approximately $10: 1$. The top-to-bottom temperature difference in the $\mathrm{CCN}$ instrument was $6^{\circ} \mathrm{C}$. Temperature set points in the TD heating section were switched between 60,80 , or $100^{\circ} \mathrm{C}$. The flow rate used for TD operation was $1.5 \mathrm{~L} \mathrm{~min}^{-1}$, corresponding to an average residence time of roughly $7 \mathrm{~s}$. In this setup, the TD was operated without a cooling section, as recondensation of vapors is minimal at low ambient mass loadings characteristic of the conditions during this study (e.g., Cappa, 2010; Saleh et al., 2011). The SMPS was operated with a sheath flow rate of $3.0 \mathrm{~L} \mathrm{~min}^{-1}$ and aerosol flow rate of $0.30 \mathrm{~L} \mathrm{~min}^{-1}$ (10:1 ratio), with the CPC 3022A in low flow mode. Aerosol size distributions were collected every $3 \mathrm{~min}$, scanning particle sizes from 14.6 to $685.4 \mathrm{~nm}$. The AMS was operated in V mode (DeCarlo et al., 2006) with a data averaging time of $3 \mathrm{~min}$. AMS measures mass concentrations of non-sea salt chloride, sulfate, nitrate, ammonium, and organics; refractory species (at $600^{\circ} \mathrm{C}$ ), including sea-salt, black carbon, and crustal material, are not detected. Separate from this setup was an additional PILS coupled with an ion chromatograph (IC), referred to hereafter as the PILS-IC, which measured the ambient water-soluble $\mathrm{Na}^{+}, \mathrm{NH}_{4}^{+}, \mathrm{K}^{+}, \mathrm{Ca}^{2+}$, $\mathrm{Mg}^{2+}, \mathrm{Cl}^{-}, \mathrm{NO}_{3}^{-}, \mathrm{NO}_{2}^{-}, \mathrm{SO}_{4}^{2-}$, as well as acetate, formate, and oxalate every $20 \mathrm{~min}$ (Orsini et al., 2003).

The sampling schedule shown in Fig. 2 was designed to allow for automated measurements of ambient and watersoluble ambient aerosol. Thermally denuded measurements were conducted from 20 June to 15 July. The temperature in the TD heating section was switched between 60 and $80^{\circ} \mathrm{C}$ 


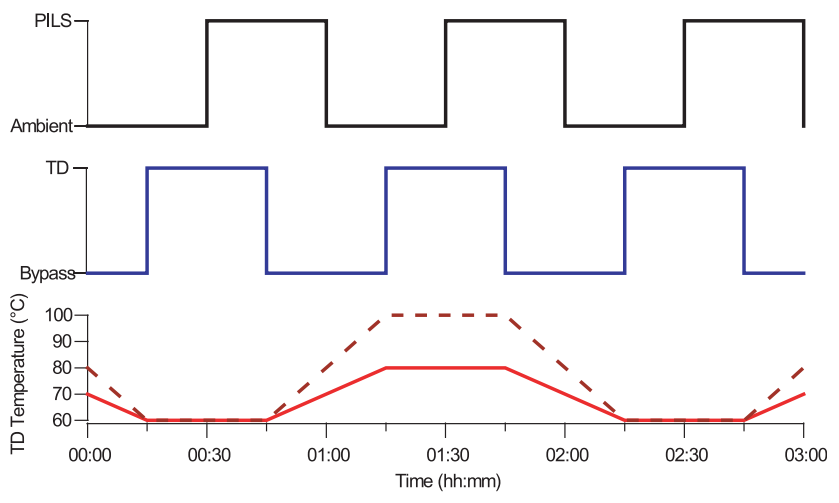

Figure 2. Example sampling schedule illustrating the valve switching between both PILS and ambient sampling lines and TD and bypass sampling lines. TD sampling temperatures from 20 June to midday 30 June are indicated by the red solid line, and sampling temperatures from evening 30 June to 15 July are indicated by the dashed line.

from 20 June to midday 30 June 2013 (Fig. 2, solid red line), and between 60 and $100^{\circ} \mathrm{C}$ from evening 30 June through 15 July 2013 (Fig. 2, dashed line). SMPS distributions and AMS spectra sampled right before or after each switch between ambient/PILS sampling lines or between bypass and TD thermal processing were discarded. This leaves three SMPS scans and AMS samples per 15 min measurement interval. CCN properties (e.g., CCN concentration as a function of $s$ ) were averaged when more than one SFCA scan occurred during a single SMPS sample. CCN spectra were smoothed by fitting CCN concentrations as a function of $s$. These fits were filtered for cases where flow rate fit parameter standard deviations (SDs) are greater than $25 \mathrm{~cm}^{3} \mathrm{~min}^{-1}$, resulting in a supersaturation uncertainty of approximately $\pm 0.03 \%$ (according to the calibration described in Sect. 3.1). The resulting $\mathrm{CCN}$ concentrations were compared with activation spectra predicted by applying Köhler theory (Köhler, 1936) to SMPS-measured concentrations under the assumption that the distributions had a $\kappa$ of approximately $0.2-0.3$, a general estimate of an aerosol population composed of organics and ammonium sulfate with equal volume fractions or slightly higher organic volume fraction than ammonium sulfate (see Sect. 3.3), as a filter to help identify irregularities in the data. All supersaturations in the instrument were corrected for supersaturation depletion from condensation of water vapor onto the activated CCN (see Sect. 3.1). Data were further filtered for days with measured precipitation $\geq 0.1 \mathrm{~mm}$ ( $5 \mathrm{~min}$ resolution precipitation data provided by Atmospheric Research \& Analysis, Inc.) and for any influences from nonrepresentative local sources (e.g., diesel exhaust from truck deliveries to the sampling site). As flow, and therefore supersaturation, is scanned in the $\mathrm{CCNc}$, spectra were divided into bins of $s(\%) \pm 0.005 \%$ and averaged within each bin.

\section{Methodology}

\subsection{Instrument calibration and supersaturation depletion}

The relationship between supersaturation and instantaneous flow rate was calibrated using the procedures of Moore and Nenes (2009). Briefly, ammonium sulfate solution is atomized, dried using two silica gel diffusion dryers, and chargeneutralized using Po-210. The dried aerosol is then classified by a differential mobility analyzer (DMA; TSI model 3081 and split between a CPC, giving the total number of condensation nuclei, and the $\mathrm{CCNc}$. The activation ratio, or ratio of $\mathrm{CCN}$ to $\mathrm{CN}$ concentration, is plotted against instantaneous flow rate and fit to a sigmoid function. The point where half of the total particles act as CCN corresponds to a "critical flow rate" and the instantaneous value of supersaturation corresponds to the known critical supersaturation, $s_{\mathrm{c}}$, of the classified ammonium sulfate (Moore and Nenes, 2009). This relationship is determined for a range of classified ammonium sulfate particles, resulting in a calibration curve, in this case ranging from 0.10 to $0.40 \%$.

The calibration method described above was conducted with ammonium sulfate aerosol concentrations below $700 \mathrm{~cm}^{-3}$ in order to avoid water vapor depletion in the instrument (Lathem and Nenes, 2011). For measurements made throughout the study, supersaturation depletion in the $\mathrm{CCNc}$ column was accounted for using the correction found in Raatikainen et al. (2014); this typically has a negligible effect when sampling low ambient number concentrations but can be important when sampling from the PILSnebulizer system (Fig. 1, green dashed line), where total aerosol number concentrations can reach as high as approximately $2.5 \times 10^{5} \mathrm{~cm}^{-3}$.

\subsection{Determining total aerosol hygroscopicity}

Aerosols activate in the $\mathrm{CCNc}$ when their critical supersaturation, $s_{\mathrm{c}}$, is greater than the instantaneous supersaturation (i.e., flow rate), $s$, in the CCNc column. This $s_{\mathrm{c}}$ corresponds to a critical diameter, $d_{\mathrm{p}, \mathrm{c}}$, above which all particles activate. These parameters are used to determine the aerosol hygroscopicity parameter, $\kappa$ (Petters and Kreidenweis, 2007):

$\kappa=\frac{4 A^{3}}{27 d_{\mathrm{p}, \mathrm{c}}^{3} s_{\mathrm{c}}^{2}}$,

where $A=\left(4 M_{\mathrm{w}} \sigma_{\mathrm{w}}\right) /\left(R T \rho_{\mathrm{w}}\right)$, and $M_{\mathrm{w}}, \sigma_{\mathrm{w}}$, and $\rho_{\mathrm{w}}$ are the molar mass, surface tension, and density, respectively, of water at the average mid-column temperature, $T$, in the $\mathrm{CCNc}$ $(305 \mathrm{~K}) . R$ is the universal gas constant. The $d_{\mathrm{p}, \mathrm{c}}$ is obtained by matching the concentration of CCN activated at a given $s$ (where $s=s_{\mathrm{C}}$ ) with the backwards integrated SMPS number distribution (thus, the corresponding size bin and $d_{\mathrm{p}, \mathrm{c}}$; Moore et al., 2011). This analysis method operates under the assumption that the aerosols are internally mixed (i.e., par- 
ticles of a given size have similar composition) and that the size-dependent hygroscopicity does not vary enough to inhibit activation at larger sizes. In cases where ambient or thermally denuded measurements are inhomogeneous, $\kappa$ is most representative of particles with sizes near $d_{\mathrm{p}, \mathrm{c}}$.

\subsubsection{Uncertainty in measured hygroscopicity}

The uncertainty in the measured $\kappa$ can be mainly attributed to uncertainties in the measured particle diameter and instrument supersaturation and can be described by

$\Delta \kappa=\sqrt{\left(\frac{\partial \kappa}{\partial s} \Delta s\right)^{2}+\left(\frac{\partial \kappa}{\partial d_{\mathrm{p}}} \Delta d_{\mathrm{p}}\right)^{2}}$,

where $\Delta s$ and $\Delta d_{\mathrm{p}}$ are the instrument uncertainties in CCNcmeasured supersaturation and DMA-measured diameter, respectively. Absolute uncertainty from $\mathrm{CCNc}$ supersaturation is estimated at $\pm 0.04 \%$ (Moore et al., 2011) while DMA sizing uncertainty, based on the width of the DMA transfer function (Wang and Flagan, 1990) and the 10:1 sheath-toaerosol flow ratio used in this study, is approximately $10 \%$. Average critical diameters of ambient aerosol of 83, 95, and $116 \mathrm{~nm}$ and measured at supersaturations of $0.40,0.30$, and $0.20 \%$, respectively, are reported and discussed in Sect. 4. Applying these values to Eq. (2) gives a $\Delta \kappa$ of $0.033,0.053$, and 0.097 for $0.40,0.30$, and $0.20 \%$ supersaturation, respectively.

\subsection{Inferring organic aerosol hygroscopicity}

Total aerosol hygroscopicity can be expressed as a sum of contributions from each aerosol component

$\kappa=\sum_{j} \varepsilon_{j} \kappa_{j}$,

where $\varepsilon_{j}$ and $\kappa_{j}$ are the volume fraction and hygroscopicity of species $j$, respectively (Petters and Kreidenweis, 2007). Using this rule, aerosols can be separated into its organic (org) and inorganic (inorg) contributions to the total measured hygroscopicity, where

$\kappa=\varepsilon_{\text {org }} \kappa_{\text {org }}+\varepsilon_{\text {inorg }} \kappa_{\text {inorg }}$.

Measurements of particle composition, in this case, can come from either AMS or PILS-IC measurements. Using the five aerosol components measured by AMS, aerosols can be separated into its primarily inorganic $\left(\left[\mathrm{NH}_{4}^{+}\right],\left[\mathrm{SO}_{4}^{2-}\right],\left[\mathrm{Cl}^{-}\right]\right.$, and $\left.\left[\mathrm{NO}_{3}^{-}\right]\right)$and organic ([Org]) mass concentrations. A typical organic density of $1.4 \mathrm{~g} \mathrm{~cm}^{-3}$ is assumed for volume calculations (e.g., Moore et al., 2011; Lathem et al., 2013). In order to better assess the properties of the inorganic aerosols, the partitioning of aerosols between sulfate species is evaluated (Nenes et al., 1998; Moore et al., 2011; Lathem et al., 2013). Using the molar ratio of ammonium ions to sulfate ions, $R_{\mathrm{SO}_{4}}$, sulfate is determined to exist as a mixture of ammonium bisulfate and sulfuric acid for $R_{\mathrm{SO}_{4}}<1$, as ammonium sulfate and ammonium bisulfate for $1<R_{\mathrm{SO}_{4}}<2$, or as ammonium sulfate for $R_{\mathrm{SO}_{4}}>2$. This method assumes that the relative contribution of nitrate (and will therefore exist mainly in the gas phase) and other inorganic cations (such as sodium) to the aerosol is minimal, which is the case here. Inorganic cations are not measured by the AMS, while nitrates are not present owing to the high acidity of the aerosol sampled (Guo et al., 2015). Once the species are determined, volume fractions are calculated using AMS mass fractions and the species densities and hygroscopicities listed in Padró et al. (2010). For mixtures of more than one compound (i.e., for the $R_{\mathrm{SO}_{4}}<1$ or $1<R_{\mathrm{SO}_{4}}<2$ cases), inorganic properties are calculated as the average of the individual component properties.

PILS-IC measurements can also be used to determine the inorganic and organic contributions to the aerosol. In this case, as measurements of $\mathrm{Na}^{+}$are included (Guo et al., 2015), it can be assessed whether the presence of these species can impact the predicted aerosol hygroscopicity. The speciation of the inorganic fraction of the aerosol becomes more complex, and the ISORROPIA II aerosol thermodynamic equilibrium model (Nenes et al., 1998; Fountoukis and Nenes, 2007) was employed to determine the mixture of inorganic salts present in the aerosol from the PILS-IC measurements. $\kappa$ and density for each of the components were taken from Padró et al. (2010) when available. Otherwise, estimated intrinsic $\kappa$ of Sullivan et al. (2009) were used with densities from Perry and Green (1997). As PILS-IC does not measure organic compounds, the AMS organic mass is used for calculation of volume fractions.

\section{Results}

The temporal variation of $\kappa$ and AMS inorganic mass fraction for ambient and PILS water-soluble aerosols at $s=$ $0.40 \%$ are shown in Fig. 3. All $\kappa$ values for this study, as shown in Fig. 3, represent the average of all $\kappa$ values measured within a given $15 \mathrm{~min}$ sampling period. Thermally denuded measurements are indicated by the set point temperature which the aerosols were exposed to in the TD. Throughout the study, the trends in ambient and PILS $\kappa$ are similar (not shown), though the magnitude can vary at different supersaturations as indicated in Table 1 . Note that the SDs in $\kappa$ in Table 1 for all conditions are typically very close to the $\Delta \kappa$ values calculated in Sect. 3.2.1; thus, it is expected that changes in the average reported $\kappa$ are robust. PILS aerosols show a slightly larger average hygroscopicity than the ambient aerosol measured at both $s=0.30 \%$ and $s=0.40 \%$. The increase in hygroscopicity of ambient aerosol with decreasing supersaturation indicates that ambient particles have increasing hygroscopicity with size; average $d_{\mathrm{p}, \mathrm{c}}$ for ambient non-denuded aerosol at $0.40,0.30$, and 
Table 1. Average (standard deviation) of $\kappa$ for the non-denuded and thermally denuded ambient and water-soluble ambient aerosol.

\begin{tabular}{lccccccc}
\hline & \multicolumn{3}{c}{ Ambient } & & \multicolumn{3}{c}{ PILS } \\
\cline { 2 - 4 } \cline { 6 - 8 }$s(\%)$ & 0.40 & 0.30 & 0.20 & & 0.40 & 0.30 & 0.20 \\
\hline Non-denuded & $0.18 \pm 0.05$ & $0.21 \pm 0.05$ & $0.25 \pm 0.08$ & & $0.25 \pm 0.06$ & $0.25 \pm 0.07$ & $0.23 \pm 0.09$ \\
TD at $60^{\circ} \mathrm{C}$ & $0.17 \pm 0.05$ & $0.20 \pm 0.06$ & $0.24 \pm 0.08$ & & $0.26 \pm 0.07$ & $0.26 \pm 0.08$ & $0.25 \pm 0.09$ \\
TD at $80^{\circ} \mathrm{C}$ & $0.19 \pm 0.08$ & $0.22 \pm 0.10$ & $0.25 \pm 0.10$ & & $0.26 \pm 0.06$ & $0.27 \pm 0.07$ & $0.27 \pm 0.12$ \\
TD at $100^{\circ} \mathrm{C}$ & $0.19 \pm 0.04$ & $0.23 \pm 0.04$ & $0.30 \pm 0.05$ & & $0.31 \pm 0.10$ & $0.27 \pm 0.10$ & $0.31 \pm 0.13$ \\
\hline
\end{tabular}

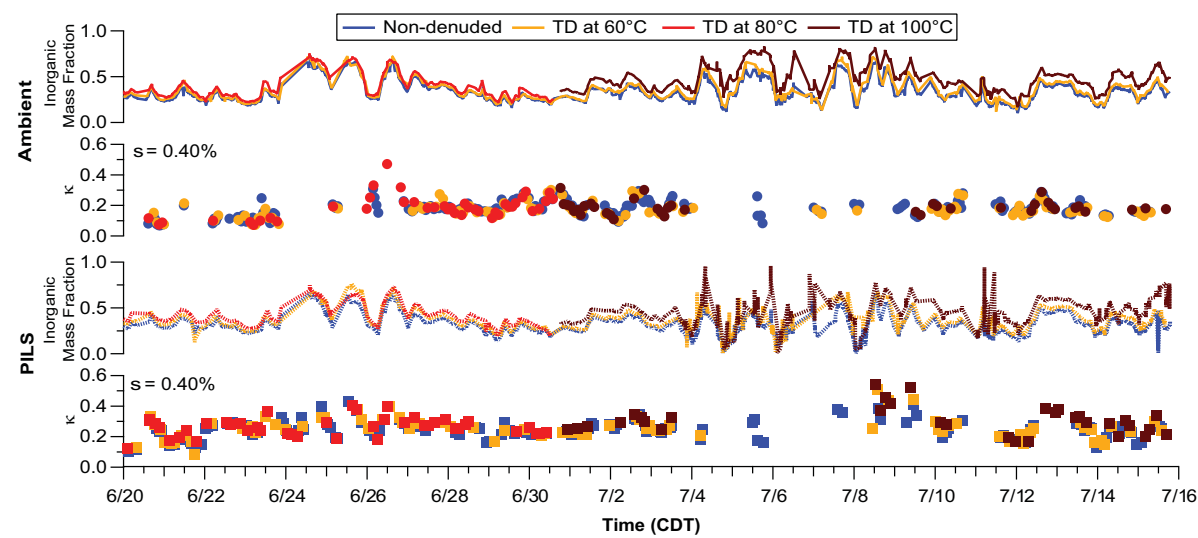

Figure 3. Temporal ambient (top) and PILS (bottom) $\kappa$ and AMS inorganic mass fractions for the entire study. Non-denuded and thermally denuded measurements are indicated by color. Each point represents an average of all $\kappa$ values measured over each 15 min sampling period.

$0.20 \% s$ are $83 \pm 9,95 \pm 9$, and $116 \pm 11 \mathrm{~nm}$, respectively. As the mixing in the PILS system results in a completely chemically homogeneous aerosol, as opposed to the ambient measurements, PILS aerosol hygroscopicity is relatively invariant with supersaturation (Table 1). Approximately $80 \%$ of the ambient aerosol measured throughout this study was found to be water-soluble and PILS aerosol composition and hygroscopicity is dominated by the mass and composition of the larger sampled aerosol sizes (Guo et al., 2015)); it is thus expected that the PILS aerosol is also representative of the bulk ambient aerosol. As such, the ambient nondenuded aerosol hygroscopicity at the largest diameters (i.e., measured at $s=0.20 \%$ ) is similar to that of the measured PILS aerosol. The previous discussion makes it reasonable to assume that any additional aqueous processes taking place in the PILS sampler have a negligible impact on the overall aerosol hygroscopicity. This assumption will be tested throughout the following analysis by comparing the properties of ambient (undenuded/denuded) aerosols measured at $s=0.20 \%$, which is expected to be most representative of the bulk aerosol and AMS measurements, and PILS aerosol measured at $s=0.40 \%$. Also, potential artifacts in the observations from semivolatile re-condensation after the thermodenuder are not expected to be important because our measurements occurred under both low aerosol mass loadings and residence times in the TD (Cappa, 2010; Saleh et al., 2011). The presence of soluble (including volatilized aerosols) gases in the CCN instrument could affect the observed aerosol hygroscopicity; very high levels of such vapors, however, are required as soluble gases tend to be lost to the wetted instrument walls before affecting $\mathrm{CCN}$ activity (Romakkaniemi et al., 2014). It is, however, possible that there may be some additional volatilization in the $\mathrm{CCN}$ instrument, especially when sampling the undenuded ambient/PILS aerosols. A future study will focus on these issues.

\section{1 $\kappa$ of thermally denuded and non-denuded aerosols}

Comparisons of the hygroscopicities of thermally denuded, referred to hereafter simply as denuded, and non-denuded aerosol sampled directly from ambient and by PILS are shown in Fig. 4. The points shown are averages of measurements taken within each 15 min sampling period and represent only those points where denuded and non-denuded samples were collected directly before or after one another. It is expected that denuding aerosols would volatilize organics; thus the remaining aerosols would have an increased inorganic fraction and display higher hygroscopicity than its non-denuded counterpart. Denuded PILS aerosols show slightly higher hygroscopicity than the non-denuded PILS aerosols, though these changes in $\kappa$ are within $10 \%$. Average thermally denuded ambient aerosols, however, display hygroscopicity similar to that of the non-denuded ambient aerosols, with some scatter that could be from the size- 

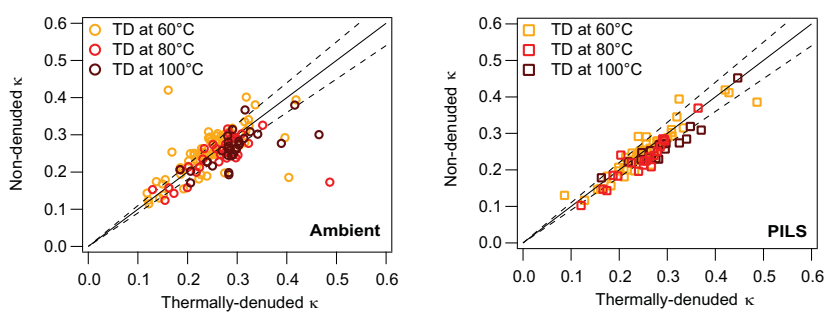

Figure 4. Non-denuded vs. thermally denuded $\kappa$ at 60,80 , and $100{ }^{\circ} \mathrm{C}$ TD sampling temperatures for ambient aerosol at $s=$ $0.20 \%$ (left) and PILS aerosol at $s=0.40 \%$ (right). The solid line represents $1: 1$ agreement while dashed lines represent deviations of $\pm 10 \%$. All points shown are for periods where non-denuded measurements are directly followed by denuded measurements and vice versa.

dependent variability of composition (that is not present in the PILS aerosol).

An unexpected result is that the ambient aerosol hygroscopicity does not change much after passing through the $\mathrm{TD}$, even when significant volatilization occurs. There are several potential reasons why this may occur. Here, it is discussed how changes in $\kappa$ are related to possible composition changes taking place in the aerosol, such as a negligible loss of mass, volatilization of inorganic material, or higher volatility compounds having higher hygroscopicity, and to the chosen measurement method. Regarding the loss of mass in the aerosol, if the aerosol is largely nonvolatile at these temperatures, a change in hygroscopicity after being thermally denuded would not be expected; this is not the case here. Average ambient aerosol mass fractions remaining calculated from AMS data and the average relative change in thermally denuded hygroscopicity, $\kappa_{\mathrm{TD}}$, vs. nondenuded hygroscopicity, $\kappa_{\mathrm{o}}$, for ambient measurements at $s=0.20 \%$ and PILS measurements at $s=0.40 \%$ are shown in Table 2. Volatilization (by mass) reaches as high as approximately $35 \%$ in the ambient aerosol and $55 \%$ in the PILS aerosol. Note that the measured mass fractions remaining are not expected to be the same for the PILS and ambient aerosols due to general shifts in composition with size expected for ambient aerosol; however, the expected changes in $\kappa$, if ambient aerosol at $s=0.20 \%$, and PILS aerosol should be relatively similar. Indeed, relative changes in hygroscopicity are, on average, only $12 \%$ for ambient mass losses of approximately $35 \%$. Villani et al. (2013) also found small changes in hygroscopicity for thermally denuded aerosol, measuring changes in subsaturated hygroscopicity generally less than $5 \%$ for thermally denuded (from 70 to $100^{\circ} \mathrm{C}$ ) aerosols measured at four unique ambient environments (Puy de Dôme, France; Clermont-Ferrand, France; Mace Head, Ireland; Leipzig, Germany). They also determined that denuded particles could display increased or decreased hygroscopicity, as seen here.
The magnitude of changes in $\kappa$ is dependent on how mass is lost in the aerosol particles after passing through the TD. Assuming that volatilization is mainly associated with organics, the change in hygroscopicity expected for the data, particularly at 80 and $100^{\circ} \mathrm{C}$ for PILS and ambient data, should be notable. For example, according to the mixing rule in Eq. (4), for a given particle composed of equal volumes of inorganic, assuming inorganic $\kappa$ equals that of ammonium sulfate of 0.6 (Petters and Kreidenweis, 2007), and organic, assuming organic $\kappa$ of 0.2 (organic $\kappa$ typically ranges from 0.1 to 0.3 ; Petters and Kreidenweis, 2007), measured $\kappa$ would equal 0.4. If the same particles were denuded and the loss of organic mass resulted in a particle that is $80 \%$ by volume inorganic and $20 \%$ by volume organic, the resulting total $\kappa$ would equal 0.52 (a $30 \%$ increase in measured $\kappa$ ). One issue that makes this argument more complex is that, while it might be expected that a majority of the mass fraction lost would be from organics, it is also known that inorganic compounds (such as ammonium sulfate) can volatilize at the temperatures set in the thermodenuder. For example, ammonium sulfate aerosol has been found to volatilize at as low as $75^{\circ} \mathrm{C}$ (Clarke, 1991; Burtscher et al., 2001; An et al., 2007), potentially decreasing the expected change in hygroscopicity after denuding. In our data, the fraction of the inorganic mass lost in the denuder did not exhibit any temperature dependence between 30 and $100^{\circ} \mathrm{C}$, indicating that volatilization is not the main cause of this phenomenon.

An additional possibility for changes in $\kappa$ to be suppressed even after loss of organic and inorganic materials (after passing through the TD) is a decrease in the remaining organic hygroscopicity after denuding. Conventional thought suggests that the more volatile the organic compounds, the less aged and less hygroscopic they are (e.g., Jimenez et al., 2009). This implies that if the lowest hygroscopicity compounds are volatilized first, the remaining organic compounds should be of higher hygroscopicity. If volatilized organic material is actually of higher $\kappa$ than the remaining organics (e.g., as seen by Asa-Awuku et al., 2009), a decrease in the hygroscopicity of the remaining organic could suppress changes seen in the total $\kappa$ after denuding.

One final and necessary component in evaluating these results and their consequences on CCN activity is to consider the effects of ambient size-resolved composition. Regarding measurement methods, as described in Sect. 3.2, the critical dry diameter, $d_{\mathrm{p}, \mathrm{c}}$, is determined by matching the CCN concentration with the backwards-integrated SMPS size distribution. Thus, $\kappa$ is expected to be most representative of aerosols with similar diameter to $d_{\mathrm{p}, \mathrm{c}}$. According to Eq. (1), $d_{\mathrm{p}, \mathrm{c}}$ at a given $s$ will change if $\kappa$ changes, as might be expected when volatilizing material in the denuder. For a mixture that is chemically homogeneous with size, as is the PILS aerosol, a change in $d_{\mathrm{p}, \mathrm{c}}$ should not have an effect on $\kappa$ (see Table 1). As the ambient aerosol display size-dependent composition (Table 1 ), changes in $d_{\mathrm{p}, \mathrm{c}}$ could potentially affect $\kappa$. Thus, it is difficult to probe the overall changes in chem- 
Table 2. Average and SD in mass fractions remaining (MFR) and relative change of thermally denuded vs. non-denuded aerosol for ambient $\kappa$ measured at $s=0.20 \%$ and PILS $\kappa$ measured at $s=0.40 \%$.

\begin{tabular}{lccccc}
\hline & \multicolumn{2}{c}{ Ambient } & & \multicolumn{2}{c}{ PILS } \\
\cline { 2 - 3 } \cline { 5 - 6 } & MFR & $\frac{\kappa_{\mathrm{TD}}-\kappa_{\mathrm{O}}}{\kappa_{\mathrm{O}}}$ & & MFR & $\frac{\kappa_{\mathrm{TD}}-\kappa_{\mathrm{O}}}{\kappa_{\mathrm{O}}}$ \\
\hline TD at $60^{\circ} \mathrm{C}$ & $0.90 \pm 0.10$ & $-0.02 \pm 0.20$ & & $0.73 \pm 0.19$ & $0.01 \pm 0.12$ \\
TD at $80^{\circ} \mathrm{C}$ & $0.78 \pm 0.05$ & $0.11 \pm 0.33$ & & $0.65 \pm 0.11$ & $0.10 \pm 0.10$ \\
$\mathrm{TD}$ at $100^{\circ} \mathrm{C}$ & $0.65 \pm 0.08$ & $0.12 \pm 0.16$ & & $0.45 \pm 0.13$ & $0.11 \pm 0.07$ \\
\hline
\end{tabular}

istry of a given particle, but it is possible to look at how changes impact $\mathrm{CCN}$ activation at a given supersaturation. These changes in hygroscopicity for a given supersaturation are a measure of the importance of volatilization on $\mathrm{CCN}$ activity. Results reported in Table 2 clearly show that even with ambient mass losses of $\sim 35 \%$, the effect of volatility on $\kappa$, and thus CCN activity, is at most $10 \%$.

\subsection{Inferred organic hygroscopicity}

Organic hygroscopicity, $\kappa_{\text {org }}$, was inferred using composition measurements from $\mathrm{PM}_{1}$ AMS and PILS-IC with ISORROPIA II and the methods described in Sect. 3.3 (Table 3). PILS-IC compositions were averaged over $1 \mathrm{~h}$ (i.e., spanning two periods of non-denuded PILS measurements in the PILS-AMS-CCNc setup). Using AMS composition and the total measured $\kappa$ to infer $\kappa_{\text {org }}$ shows that, the less volatile organic aerosol is also less hygroscopic. Though the SDs in $\kappa_{\text {org }}$ are nearly as large as the average $\kappa_{\text {org }}$ values (Table 3 ), the consistent trend between PILS and ambient aerosols, with the possible exception of ambient $\kappa_{\text {org }}$ at $80{ }^{\circ} \mathrm{C}$ (where the highest SD is also seen), suggests that the most volatile fraction in the aerosol actually is of higher hygroscopicity than the less volatile material. Though this contradicts the conventional view that the most volatile aerosol components are the least hygroscopic, the change in hygroscopicity of only the organic fraction of the aerosol with volatility has not been studied in the ambient environment to the knowledge of these authors. Such behavior has been seen in chamber-generated aerosols (e.g., Asa-Awuku et al., 2009; Meyer et al., 2009). It is possible that the least volatile fraction is also the least hygroscopic due to the presence of oligomers: high molecular weight compounds with low volatility and solubility - hence hygroscopicity (e.g., Ervens et al., 2011; Li et al., 2011; Sareen et al., 2010; Asa-Awuku et al., 2009; Reynolds et al., 2006; Varutbangkul et al., 2006; Dommen et al., 2006; Baltensperger et al., 2005; VanReken et al., 2005; Kalberer et al., 2004). As temperature is increased in the thermodenuder, oligomers may partially dissociate into more volatile and hygroscopic fragments upon heating, contributing to the decreased hygroscopicity at increased temperatures in the TD (Table 3).

To evaluate the importance of assumptions of the inorganic composition in inferring the organic hygroscopicity, $\kappa_{\text {org }}$ was additionally determined for non-denuded PILS aerosols using data from a PILS-IC system concurrently sampling nondenuded ambient aerosols and located separately from the main PILS-CCNc-AMS setup. Data were input into the ISORROPIA II aerosol equilibrium model to determine speciated composition of the inorganics, investigating how realistic the assumptions are of treating the inorganic hygroscopicity as an ammonium and sulfate system only (Sect. 3.3). ISORROPIA II is able to resolve sodium, ammonium, magnesium, calcium, and potassium species. In Centreville, however, sodium, magnesium, calcium, and potassium components were found to typically be negligible. For this reason, there should be little difference in the assumed inorganic hygroscopicity using the AMS or PILS-IC analysis methods. The slight decrease in ambient PILS $\kappa_{\text {org }}(\sim 0.03$; Table 3$)$ resulting from PILS-IC vs. AMS analysis confirms the validity of using simplified assumptions of aerosol speciation to calculate inorganic hygroscopicity for this study and does not change the trend of decreased $\kappa_{\text {org }}$ with increased volatility seen here.

\subsection{Organic aerosol hygroscopicity and degree of oxidation}

The potential link between organic hygroscopicity and the level of aerosol oxidation is investigated using AMS measurements of the bulk $\mathrm{O}: \mathrm{C}$ ratio with the $\kappa_{\text {org }}$ determined in Sect. 4.2 with. O : C throughout the study and for different TD sampling temperatures varied slightly with ambient average $\mathrm{O}: \mathrm{C}$ values of $0.58 \pm 0.06$ for non-denuded aerosols; no variation in average $\mathrm{O}: \mathrm{C}$ was seen for denuded aerosols, being $0.59 \pm 0.05,0.57 \pm 0.04$, and $0.59 \pm 0.06$ for TD temps of 60,80 , and $100^{\circ} \mathrm{C}$, respectively (Fig. 5, left). PILSgenerated aerosol showed similar $\mathrm{O}: \mathrm{C}$ values of $0.55 \pm 0.04$, $0.57 \pm 0.05,0.56 \pm 0.03$, and $0.53 \pm 0.07$ for non-denuded and denuded aerosol at 60,80 , and $100^{\circ} \mathrm{C}$, respectively (Fig. 5, right). There is no clear relationship between $\kappa_{\text {org }}$ with $\mathrm{O}: \mathrm{C}$ for any of these data as the correlation between $\kappa_{\text {org }}$ and $\mathrm{O}: \mathrm{C}$ in all cases is low $\left(R^{2}<0.23\right.$ for ambient and $<0.53$ for PILS aerosol).

The relationship between $\kappa_{\text {org }}$ with average carbon oxidation state $\overline{\mathrm{OS}}_{\mathrm{c}}$, calculated as $2 \times \mathrm{O}: \mathrm{C}-\mathrm{H}: \mathrm{C}$ (where $\mathrm{H}: \mathrm{C}$ is the hydrogen-to-carbon ratio of the aerosol measured by the AMS) is further investigated for the ambient aerosol 
Table 3. Average and SD in $\kappa_{\text {org }}$ of non-denuded and denuded ambient aerosol at $s=0.20 \%$ and water-soluble ambient aerosol at $s=0.40 \%$ using bulk AMS composition and PILS-IC with ISORROPIA II composition.

\begin{tabular}{lccc}
\hline & \multicolumn{2}{c}{ AMS } & PILS-IC \\
\cline { 2 - 3 } & Ambient $(s=0.20 \%)$ & PILS $(s=0.40 \%)$ & PILS $(s=0.40 \%)$ \\
\hline Non-denuded & $0.14 \pm 0.09$ & $0.14 \pm 0.06$ & $0.11 \pm 0.07$ \\
TD at $60^{\circ} \mathrm{C}$ & $0.12 \pm 0.08$ & $0.12 \pm 0.06$ & - \\
TD at $80^{\circ} \mathrm{C}$ & $0.12 \pm 0.11$ & $0.09 \pm 0.04$ & - \\
TD at $100^{\circ} \mathrm{C}$ & $0.08 \pm 0.07$ & $0.08 \pm 0.06$ & - \\
\hline
\end{tabular}
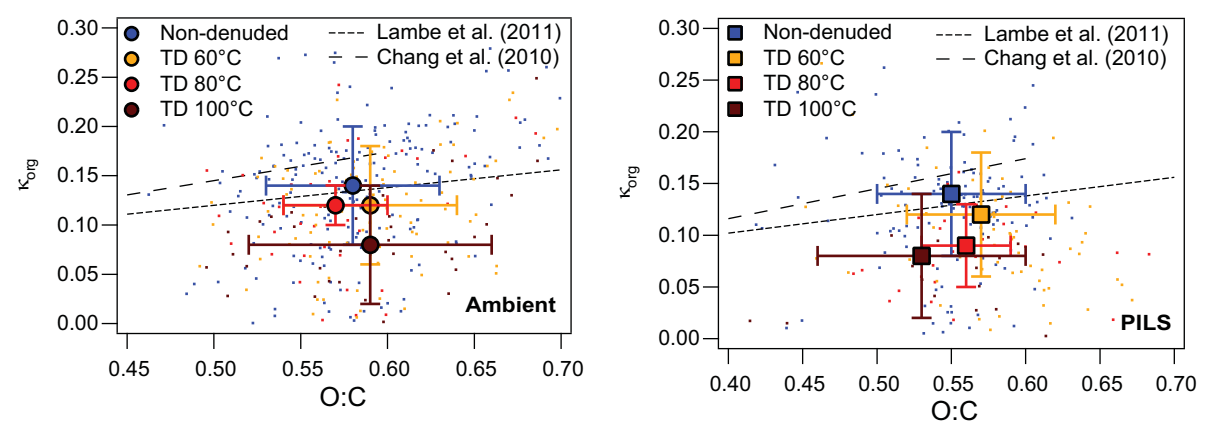

Figure 5. Variation in $\kappa_{\text {org }}$ with O : C for ambient aerosol at $s=0.20 \%$ and PILS aerosol at $s=0.40 \%$ for non-denuded and thermally denuded conditions. Small colored dots indicate all measured points while larger circles and squares indicate the averages. Errors bars indicate 1 standard deviation in measured values for ambient and PILS aerosols. Also shown are dashed lines indicating the parameterizations of $\kappa_{\text {org }}$ with O : C from Lambe et al. (2011) and Chang et al. (2010).

(Fig. 6, left panel). While there is no clear relationship between $\kappa_{\text {org }}$ and oxidation in terms of $\overline{\mathrm{OS}}_{\mathrm{c}}$, it appears that denuded aerosols at $100^{\circ} \mathrm{C}$ are more oxidized than at other temperatures, as might be expected, but this is not indicated by $\mathrm{O}$ : C. Measurements at $80^{\circ} \mathrm{C}$, though, still appear to be less oxidized than thermally denuded at $60^{\circ} \mathrm{C}$. Although at first this seems counterintuitive (Sect. 2.2 and Figs. 2 and 3), $60{ }^{\circ} \mathrm{C}$ measurements were taken throughout the measurement period while $80^{\circ} \mathrm{C}$ were taken only during the beginning portion of the study and $100^{\circ} \mathrm{C}$ only during the latter portion of the study. Therefore, it is more appropriate to focus on the relationship between $\kappa_{\mathrm{org}}$ and $\overline{\mathrm{OS}}_{\mathrm{c}}$ for each separate measurement period (Fig. 6, right). In this case, $\overline{\mathrm{OS}}_{\mathrm{c}}$ is consistent with expectation that oxidation increases as more material is volatilized in the denuder as indicated by the change in $\overline{\mathrm{OS}}_{\mathrm{c}}$ between non-denuded, 60 , and $100^{\circ} \mathrm{C}$ measurements (Fig. 6, right, bottom) with comparable increases in $\overline{\mathrm{OS}}_{\mathrm{c}}$ for 60 and $80^{\circ} \mathrm{C}$ measurements compared to non-denuded measurements (Fig. 6, right, top). This is not, however, the case for $\mathrm{O}: \mathrm{C}$, as $\mathrm{O}: \mathrm{C}$ of $60^{\circ} \mathrm{C}$ measurements remains greater than that of $100^{\circ} \mathrm{C}$ measurements (not shown). $\mathrm{O}: \mathrm{C}$ of 60 , $80^{\circ} \mathrm{C}$, and non-denuded measurements are comparable (not shown). Overall, $\overline{\mathrm{OS}}_{\mathrm{c}}$ appears to be more consistent with the expectation of the least volatile fraction being the most oxidized while $\mathrm{O}: \mathrm{C}$ appears to show no correlation with volatilization. Even $\overline{\mathrm{OS}}_{\mathrm{c}}$, however, may appear counter to expectation during portions of the sampling period (Fig. 6, left); this is a result of changing air masses which can change the relationship between hygroscopicity and volatility with oxidation. Furthermore, the increase in $\overline{\mathrm{OS}}_{\mathrm{c}}$ with volatility is still consistent with the potential presence of oligomers discussed in Sect. 4.2.

\subsection{Attributing organic hygroscopicity to AMS factors}

Positive matrix factorization (PMF; Lanz et al., 2007) analysis is performed on high-resolution organic mass spectra for source apportionment. A detailed discussion of the PMF results can be found in Xu et al. (2015). In brief, four subtypes of OA are identified in the ambient aerosol after carefully examining the scaled residual, solution rotational ambiguity, and factor correlations with external tracers. Two oxygenated $\mathrm{OA}$ factors with high but differing $\mathrm{O}: \mathrm{C}$ ratios are termed more-oxidized oxygenated organic aerosols (MO-OOA, $\mathrm{O}: \mathrm{C}=0.8$ ) and less-oxidized OOA (LO-OOA, $\mathrm{O}: \mathrm{C}=0.46)$. MO-OOA contributes $39 \%$ of total OA. LOOOA, accounting for $32 \%$ of OA, is found to be mainly from $\beta$-pinene oxidation by $\mathrm{NO}_{3}$ radical. Biomass burning OA (BBOA) factor, characterized by ions at $m / z 60\left(\mathrm{C}_{2} \mathrm{H}_{4} \mathrm{O}_{2}^{+}\right)$ and $73\left(\mathrm{C}_{3} \mathrm{H}_{5} \mathrm{O}_{2}^{+}\right)$in the mass spectrum, shows good correlation $(R=0.8)$ in time series with brown carbon. The fourth factor is interpreted as isoprene-derived OA (isoprene-OA). This factor exhibits a similar mass spectrum to laboratorygenerated isoprene SOA via the reactive uptake of epoxy- 

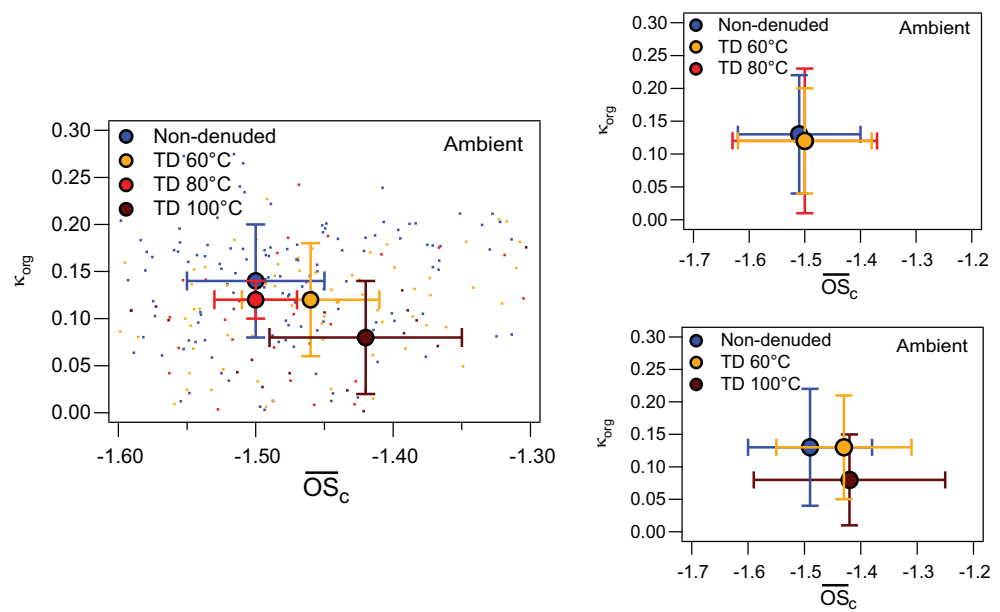

Figure 6. Variation in $\kappa_{\mathrm{org}}$ with $\overline{\mathrm{OS}}_{\mathrm{c}}$ for ambient aerosol at $s=0.20 \%$ for the total study period (left) and for 80 and $100{ }^{\circ} \mathrm{C}$ measurement periods only (right top and bottom, respectively). Small colored dots indicate all measured points while larger circles indicate measurement averages and errors bars indicate a single SD in measured values.

diols (prominent signals at $\mathrm{C}_{4} \mathrm{H}_{5}^{+}$and $\mathrm{C}_{5} \mathrm{H}_{6} \mathrm{O}^{+}$) ( $\mathrm{Li}$ et al., 2012; Nguyen et al., 2014). Additionally, it shows a good correlation with particle-phase methyltetrols (tracer for isoprene $\mathrm{OA})$. PMF on the PILS aerosol resulted in three factors corresponding to LO-OOA, MO-OOA, and isoprene-OA; this is because during the period of measurements with the PILS, the concentration of BBOA was too low to expect a PMF factor to emerge from the analysis. PMF factors of the total PILS aerosol measured by AMS were used to perform linear regression on the PILS non-denuded $\kappa_{\text {org }}$ (at $s=0.40 \%$ ) to infer the hygroscopicity of each PMF factor, and its contribution to organic aerosol hygroscopicity:

$$
\begin{aligned}
\kappa_{\text {org }} & =\varepsilon_{\text {LO-OOA }} \kappa_{\mathrm{LO}-\mathrm{OOA}}+\varepsilon_{\mathrm{MO}-\mathrm{OOA}} \kappa_{\mathrm{MO}-\mathrm{OOA}} \\
& +\varepsilon_{\text {isoprene-OA }} \kappa_{\text {isoprene-OA }},
\end{aligned}
$$

where properties are representative of AMS mass spectra for LO-OOA, MO-OOA, and isoprene-OA. A system of equations is determined using corresponding measurements of the PILS non-denuded $\kappa_{\text {org }}$ and PMF factor mass fractions. A bootstrapped resampling of the regression indicates that while the average $\kappa_{\mathrm{MO}-\mathrm{OOA}}$ and $\kappa_{\text {isoprene-OA }}$ are similar at $0.16 \pm 0.02$ and $0.20 \pm 0.02$, respectively, they are at least twice as large as the average $\kappa_{\text {LO-OOA }}$ of $0.08 \pm 0.02$ (Fig. 7).

As a consistency check, the values of hygroscopicity parameter determined in Fig. 7 are compared against those retrieved from non-denuded ambient $\kappa_{\text {org }}$ measurements. Given that non-denuded PILS-derived $\kappa_{\text {org }}$ does not contain biomass burning influence and the method works best for an aerosol that is chemically uniform with size (e.g., Cerully et al., 2011), we analyze ambient data during periods where PILS data are available and for which the biomass burning factor in the ambient aerosol was less than $1 \%$ of the total organic aerosol. This constraint filtered out periods of data when the aerosol was an external mixture, as
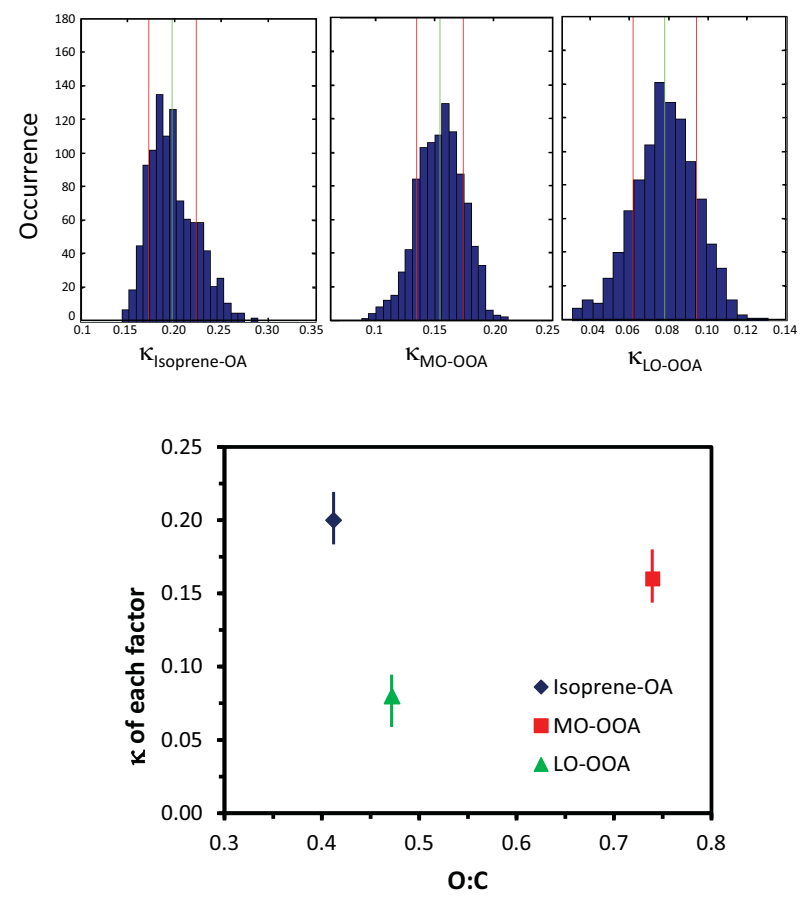

Figure 7. (top) Examples of binned $\kappa_{\text {org }}$ solutions from a bootstrapped resampling of the linear regression of the CCN activity of PILS bypass aerosol, where the solid green and red lines represent the average and $1 \mathrm{SD}$, respectively, in each factor. (bottom) $\kappa_{\mathrm{org}}$ found for each PMF factor through linear regression vs. O : C for non-denuded PILS aerosol at $s=0.40 \%$, where error bars represent the SD obtained from the bootstrap analysis.

the aerosol was unimodal (not shown) and more consistent with the requirement of chemical uniformity. The filtered data were then processed to infer the $\kappa_{\text {org }}$ by application of Eq. (5). A subsequent bootstrap analysis led to values 

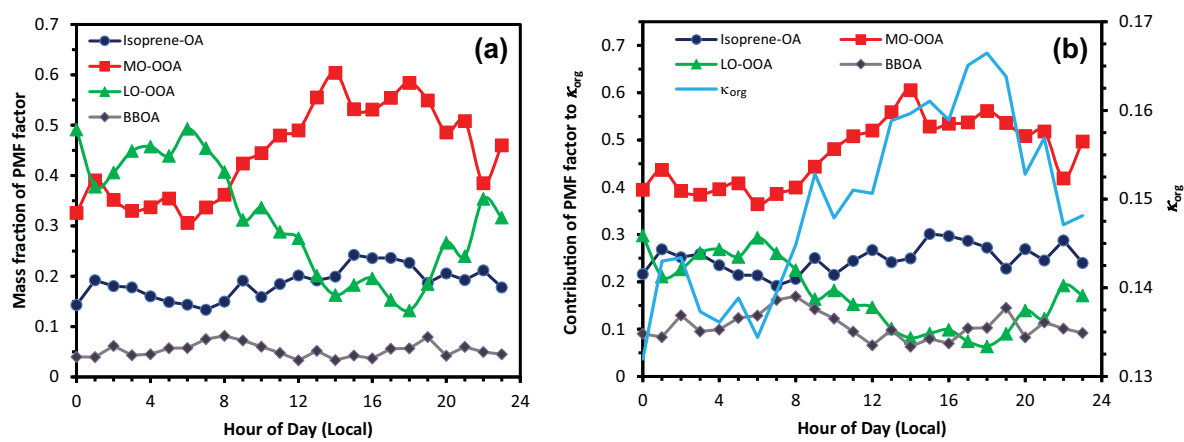

Figure 8. (a) Average mass fraction diurnal profile of the three characteristic aerosol factors identified in the AMS spectra. (b) The corresponding diurnal contribution of each aerosol factor to the $\kappa_{\mathrm{org}}$, computed by multiplying the mass fraction by the corresponding hygroscopicity parameter (Fig. 7) and the predicted diurnal profile of the total $\kappa_{\text {org }}$ in the ambient aerosol.

of the hygroscopicity parameter that were very similar to those shown in Fig. $7: \kappa_{\text {isoprene-OA }}=0.26 \pm 0.07 ; \kappa_{\mathrm{MO}-\mathrm{OOA}}=$ $0.17 \pm 0.05 ; \kappa_{\text {LO-OOA }}=0.1 \pm 0.03$. The broader SDs of the ambient factor analysis are a consequence of the inherently larger uncertainty associated with ambient aerosol analysis; nevertheless the analysis indicates that isoprene-OA is the most hygroscopic factor, followed by MO-OOA and LOOOA. Furthermore, the PMF factor spectra remain largely unaltered by the volatilization (E. Kostenidou, personal communication, 2015); hence the hygroscopicities in the ambient and PILS TD aerosols are not expected to be affected by the volatilization process.

$\mathrm{O}: \mathrm{C}$ values of the MO-OOA, LO-OOA, and isopreneOA factors were determined to be, respectively, 0.73, 0.47, and 0.41 (Fig. 7) by following the procedure in Aiken et al. (2008). MO-OOA displays a higher $\kappa_{\text {org }}$ and O : C compared to LO-OOA, but $\kappa_{\text {org }}$ does not clearly correlate with $\mathrm{O}: \mathrm{C}$ for all three factors. It is difficult to determine why isoprene-OA displays the lowest $\mathrm{O}: \mathrm{C}$ and the highest value of $\kappa_{\mathrm{org}}$, though this topic presents itself as an interesting area of future study. The results of $\mathrm{O}: \mathrm{C}$ with $\kappa_{\text {org }}$ of each PMF factor are comparable to that of $\overline{\mathrm{OS}}_{\mathrm{c}}$ with each factor $\kappa_{\mathrm{org}}$ (not shown).

From the average diurnal profile of the AMS mass factors (Fig. 8a) and the hygroscopicity parameter of each, one can then attribute the contribution of each factor to the overall $\kappa_{\text {org }}$. This is important, because it indicates the origin of aerosol hygroscopicity throughout the day. Given that the biomass burning factor constituted roughly $10 \%$ of the mass of the aerosol during the period sampled by the PILS, its contribution to total $\kappa_{\text {org }}$ is small but not negligible. We therefore determine an optimal estimate of its hygroscopicity, $\kappa_{\mathrm{BBOA}}$, by least squares fitting of the ambient $\kappa_{\text {org }}$ for the whole sampling period to predictions using the PMF factors mass fractions and the mean values of $\kappa_{\text {isoprene-OA }} \kappa_{\mathrm{MO}-\mathrm{OOA}}$, and $\kappa_{\mathrm{LO}-\mathrm{OOA}}$ shown in Fig. 7 ; we find that $\kappa_{\mathrm{BBOA}}=0.31$, which is at the upper limit of hygroscopicity observed from biomass burning samples (e.g., Asa-Awuku et al., 2008). Based on this set of hygroscopicity parameters and the mass fractions presented in Fig. 8a, we then can determine the contribution of each mass factor to $\kappa_{\mathrm{org}}$, and the resulting diurnal profile of $\kappa_{\text {org }}$ all of which is shown in Fig. 8b. From the results it is clear that $40-60 \%$ of the organic hygroscopicity originates from LO-OOA and another 20-30 \% from isoprene-OA. The relatively low hygroscopicity of LO-OOA and its opposing diurnal cycle with respect to MO-OOA work synergistically with LO-OOA and isoprene-OA to yield the relative invariance of $\kappa_{\mathrm{org}}$ with time of day. Biomass burning has a minor $10-15 \%$ contribution to $\kappa_{\mathrm{org}}$; given that the value of $\kappa_{\mathrm{BB}-\mathrm{OOA}}$ is highly unlikely to go above 0.3 , this constitutes an upper limit of BBOA contribution to hygroscopicity.

\section{Conclusions}

The volatility, hygroscopicity, and oxidation state of ambient and water-soluble ambient aerosols collected in a rural site in the southeastern United States during the SOAS field campaign were investigated. $\kappa$ measured at $0.40,0.30$, and $0.20 \%$ supersaturation indicated that ambient aerosol exhibited size-dependent composition. Average $\kappa$ at $s=0.20 \%$ for thermally denuded and non-denuded ambient aerosol display a strong similarity with PILS-generated aerosol at all supersaturations; $\kappa$ of PILS aerosol at $s=0.40 \%$ and ambient aerosol at $s=0.20 \%$ were compared and found to be remarkably similar throughout the study period, suggesting that the PILS aerosols were representative of the $\mathrm{PM}_{1}$ average composition.

$\kappa$ of thermally denuded aerosol at 60,80 , and $100^{\circ} \mathrm{C}$ showed similar results for both ambient and PILS-generated aerosol with $\kappa$ increasing slightly with temperature and showing a much weaker dependence on volatilization than expected. Even after volatilizing $\sim 35 \%$ of the ambient aerosol mass, relative changes in $\kappa$ for PILS-generated and ambient aerosols are only approximately $12 \%$. If this finding is representative of other locations, this could mean that 
changes in volatility may be of minor significance in the case of bulk aerosol hygroscopic properties.

The hygroscopicity of the organic fraction, $\kappa_{\text {org }}$, remaining in the aerosol after volatilization was found to decrease slightly, which is against conventional thinking that the highest volatility compounds are the least hygroscopic. This trend has been observed previously in the laboratory (e.g., AsaAwuku et al., 2009) and could be attributed to the presence of oligomers in the aerosol that dissociate into more volatile and more hygroscopic fragments upon heating. The least volatile aerosol did appear to be the most oxidized, as expected. This, however, was only indicated by $\overline{\mathrm{OS}}_{\mathrm{c}}$, while no clear correlation was seen between $\mathrm{O}: \mathrm{C}$ with volatility or hygroscopicity, consistent with the notion that $\overline{\mathrm{OS}}_{\mathrm{c}}$ is a preferred indicator of oxidation (Kroll et al., 2011). Results of AMS three-factor PMF analysis for the PILS aerosol were used to attribute the organic hygroscopicity of each PMF factor to the total $\kappa_{\text {org }}$. $\kappa_{\mathrm{MO}-\mathrm{OOA}}$ and $\kappa_{\text {isoprene-OA }}$ showed the largest hygroscopicities of $0.16 \pm 0.02$ and $0.20 \pm 0.02$, respectively, and $\kappa_{\text {LO-OOA }}$ showed a 2 -fold lower hygroscopicity of $0.08 \pm 0.02$. These parameters were verified against independent hygroscopicity retrievals for the ambient aerosol during periods when the contribution of biomass burning was negligible. No clear relationship between organic hygroscopicity and $\mathrm{O}: \mathrm{C}$ was found for all factors, particularly as $\mathrm{O}: \mathrm{C}$ in this study varies only slightly (average $\mathrm{O}: \mathrm{C}$ of non-denuded and thermally denuded ambient measurements range from only $0.59 \pm 0.05$ to $0.57 \pm 0.04)$. The hygroscopicity and $\mathrm{O}: \mathrm{C}$ of MO-OOA, however, were greater than that of LO-OOA, consistent with expectations. However, isoprene-OA was found to be the most hygroscopic factor and was also the least oxidized (and likely the most volatile), which goes against expectations. Similar results were found when compared to $\overline{\mathrm{OS}}_{\mathrm{c}}$ as an indicator of aerosol oxidation.

Some important implications arise from this study. First, for the range of hygroscopicities measured, although still within the reported ranges (0.08-0.2) for organic aerosol, the most hygroscopic components are likely the most and least volatile features of the aerosol. This leads to a relative invariance in organic aerosol properties, as both local production and long-range transport of organics can equally contribute to water uptake; hence the climate forcing associated with organic aerosol. Wet processing of the aerosol by generating new particles from the ambient soluble material collected in the PILS does not result in aerosol properties fundamentally different from those determined in the ambient aerosol, which means that deliquescence/efflorescence of aerosols in clouds does not alter the hygroscopic properties of each organic aerosol factor. Volatilization of the aerosol also does not appreciably affect its hygroscopicity, implying that semivolatile partitioning during dilution from boundary layer expansion, transport away from source region, and entrainment into the free troposphere primarily affect organic aerosol mass and not its water uptake properties. Considering the diurnal variation of each PMF factor and its asso- ciated hygroscopicity, isoprene-OA and MO-OOA are the prime contributors to hygroscopicity and co-vary with LOOOA in a way that induces the observed diurnal cycle in organic hygroscopicity. BBOA contributes here a minor role in aerosol hygroscopicity, which is expected since there was little biomass burning activity during the sampling period examined.

Acknowledgements. This study was supported by the National Science Foundation under grant ATM-1242258, Environmental Protection Agency STAR Grant R835410, and the National Oceanic and Atmospheric Administration CPO Award 538 NA10OAR4310102. A. Nenes also acknowledges the support from a Georgia Power Faculty Scholar Chair and a Cullen-Peck faculty fellowship from the Georgia Institute of Technology. The research project is implemented within the framework of the Action "Supporting of Postdoctoral Researchers" of the Operational Program "Education and Lifelong Learning" (action's beneficiary: General Secretariat for Research and Technology) and is co-financed by the European Social Fund (ESF) and the Greek State. We thank the many collaborators and scientists in the SOAS field mission, especially Karsten Baumman and Atmospheric Research \& Analysis, Inc. for precipitation data as well as Ann Marie Carlton, Neha Sareen, and Khoi Nguyen of Rutgers University for thoughtful scientific discussion.

Edited by: W. Birmili

\section{References}

Aiken, A. C., DeCarlo, P. F., Kroll, J. H., Worsnop, D. R., Huffman, J. A., Docherty, K. S., Ulbrich, I. M., Mohr, C., Kimmel, J. R., Sueper, D., Sun, Y., Zhang, Q., Trimborn, A., Northway, M., Ziemann, P. J., Canagaratna, M. R., Onasch, T. B., Alfarra, M. R., Prevot, A. S. H., Dommen, J., Duplissy, J., Metzger, A., Baltensperger, U., and Jimenez, J. L.: O / C and $\mathrm{OM} / \mathrm{OC}$ ratios of primary, secondary, and ambient organic aerosols with high-resolution time-of-flight aerosol mass spectrometry, Environ. Sci. Technol., 42, 4478-4485, 2008.

Alfarra, M. R., Good, N., Wyche, K. P., Hamilton, J. F., Monks, P. S., Lewis, A. C., and McFiggans, G.: Water uptake is independent of the inferred composition of secondary aerosols derived from multiple biogenic VOCs, Atmos. Chem. Phys., 13, 1176911789, doi:10.5194/acp-13-11769-2013, 2013.

An, W. J., Pathak, R. K., Lee, B.-H., and Pandis, S. N.: Aerosol volatility measurement using an improved thermodenuder: application to secondary organic aerosol, J. Aerosol Sci., 38, 305-314, doi:10.1016/j.jaerosci.2006.12.002, 2007.

Asa-Awuku, A., Sullivan, A. P., Hennigan, C. J., Weber, R. J., and Nenes, A.: Investigation of molar volume and surfactant characteristics of water-soluble organic compounds in biomass burning aerosol, Atmos. Chem. Phys., 8, 799-812, doi:10.5194/acp8-799-2008, 2008.

Asa-Awuku, A., Engelhart, G. J., Lee, B. H., Pandis, S. N., and Nenes, A.: Relating CCN activity, volatility, and droplet growth kinetics of $\beta$-caryophyllene secondary organic aerosol, Atmos. Chem. Phys., 9, 795-812, doi:10.5194/acp-9-795-2009, 2009. 
Baltensperger, U., Kalberer, M., Dommen, J., Paulsen, D., Alfarra, M. R., Coe, H., Fisseha, R., Gascho, A., Gysel, M., Nyeki, S., Sax, M., Steinbacher, M., Prevot, A. S. H., Sjögren, S., Weingartner, E., and Zenobi, R.: Secondary organic aerosols from anthropogenic and biogenic precursors, Faraday Discuss., 130, 265-278, doi:10.1039/B417367H, 2005.

Burtscher, H., Baltensperger, U., Bukowiecki, N., Cohn, P., Hüglin, C., Mohr, M., Matter, U., Nyeki, S., Schmatloch, V., Streit, N., and Weingartner, E.: Separation of volatile and non-volatile aerosol fractions by thermodesorption: instrumental development and applications, J. Aerosol Sci., 32, 427-442, doi:10.1016/S0021-8502(00)00089-6, 2001.

Cappa, C. D.: A model of aerosol evaporation kinetics in a thermodenuder, Atmos. Meas. Tech., 3, 579-592, doi:10.5194/amt3-579-2010, 2010.

Carlton, A. G. and Turpin, B. J.: Particle partitioning potential of organic compounds is highest in the Eastern US and driven by anthropogenic water, Atmos. Chem. Phys., 13, 10203-10214, doi:10.5194/acp-13-10203-2013, 2013.

Cerully, K. M., Raatikainen, T., Lance, S., Tkacik, D., Tiitta, P., Petäjä, T., Ehn, M., Kulmala, M., Worsnop, D. R., Laaksonen, A., Smith, J. N., and Nenes, A.: Aerosol hygroscopicity and CCN activation kinetics in a boreal forest environment during the 2007 EUCAARI campaign, Atmos. Chem. Phys., 11, 12369-12386, doi:10.5194/acp-11-12369-2011, 2011.

Cerully, K. M., Hite, J., McLaughlin, M., and Nenes, A.: Towards the determination of joint volatility-hygroscopicity distributions: instrument development and response characterization for single-component aerosol, Aerosol. Sci. Tech., 48, 296-312, doi:10.1080/02786826.2013.870326, 2014.

Chang, R. Y.-W., Slowik, J. G., Shantz, N. C., Vlasenko, A., Liggio, J., Sjostedt, S. J., Leaitch, W. R., and Abbatt, J. P. D.: The hygroscopicity parameter $(\kappa)$ of ambient organic aerosol at a field site subject to biogenic and anthropogenic influences: relationship to degree of aerosol oxidation, Atmos. Chem. Phys., 10, 5047-5064, doi:10.5194/acp-10-5047-2010, 2010.

Clarke, A. D.: A thermo-optic technique for in situ analysis of sizeresolved aerosol physicochemistry, Atmos. Environ., 25, 635644, doi:10.1016/0960-1686(91)90061-B, 1991.

DeCarlo, P. F., Kimmel, J. R., Trimborn, A., Northway, M. J., Jayne, J. T., Aiken, A. C., Gonin, M., Fuhrer, K., Horvath, T., Docherty, K. S., Worsnop, D. R., and Jimenez, J. L.: Fielddeployable, high-resolution, time-of-flight aerosol mass spectrometer, Anal. Chem., 78, 8281-8289, doi:10.1021/ac061249n, 2006.

Dommen, J., Metzger, A., Duplissy, J., Kalberer, M., Alfarra, M. R., Gascho, A., Weingartner, E., Prevot, A. S. H., Verheggen, B., and Baltensperger, U.: Laboratory observation of oligomers in the aerosol from isoprene/ $\mathrm{NO}_{x}$ photooxidation, Geophys. Res. Lett., 33, L13805, doi:10.1029/2006GL026523, 2006.

Donahue, N. M., Robinson, A. L., and Pandis, S. N.: Atmospheric organic particulate matter: from smoke to secondary organic aerosol, Atmos. Environ., 43, 94-106, doi:10.1016/j.atmosenv.2008.09.055, 2009.

Duplissy, J., DeCarlo, P. F., Dommen, J., Alfarra, M. R., Metzger, A., Barmpadimos, I., Prevot, A. S. H., Weingartner, E., Tritscher, T., Gysel, M., Aiken, A. C., Jimenez, J. L., Canagaratna, M. R., Worsnop, D. R., Collins, D. R., Tomlinson, J., and Baltensperger, U.: Relating hygroscopicity and composition of or- ganic aerosol particulate matter, Atmos. Chem. Phys., 11, 11551165, doi:10.5194/acp-11-1155-2011, 2011.

Ervens, B., Turpin, B. J., and Weber, R. J.: Secondary organic aerosol formation in cloud droplets and aqueous particles (aqSOA): a review of laboratory, field and model studies, Atmos. Chem. Phys., 11, 11069-11102, doi:10.5194/acp-1111069-2011, 2011.

Ervens, B., Wang, Y., Eagar, J., Leaitch, W. R., Macdonald, A. M., Valsaraj, K. T., and Herckes, P.: Dissolved organic carbon (DOC) and select aldehydes in cloud and fog water: the role of the aqueous phase in impacting trace gas budgets, Atmos. Chem. Phys., 13, 5117-5135, doi:10.5194/acp-13-5117-2013, 2013.

Fountoukis, C. and Nenes, A.: ISORROPIA II: a computationally efficient thermodynamic equilibrium model for $\mathrm{K}^{+}$ $\mathrm{Ca}^{2+}-\mathrm{Mg}^{2+}-\mathrm{NH}_{4}^{+}-\mathrm{Na}^{+}-\mathrm{SO}_{4}^{2-}-\mathrm{NO}_{3}-\mathrm{Cl}^{-}-\mathrm{H}_{2} \mathrm{O}$ aerosols, Atmos. Chem. Phys., 7, 4639-4659, doi:10.5194/acp-7-4639-2007, 2007.

Frosch, M., Bilde, M., DeCarlo, P. F., Jurányi, Z., Tritscher, T., Dommen, J., Donahue, N. M., Gysel, M., Weingartner, E., and Baltensperger, U.: Relating cloud condensation nuclei activity and oxidation level of $\alpha$-pinene secondary organic aerosols, J. Geophys. Res., 116, D22212, doi:10.1029/2011JD016401, 2011.

Frosch, M., Bilde, M., Nenes, A., Praplan, A. P., Jurányi, Z., Dommen, J., Gysel, M., Weingartner, E., and Baltensperger, U.: CCN activity and volatility of $\beta$-caryophyllene secondary organic aerosol, Atmos. Chem. Phys., 13, 2283-2297, doi:10.5194/acp13-2283-2013, 2013.

Goldstein, A. H. and Galbally, I. E.: Known and unexplored organic constituents in the Earth's atmosphere, Environ. Sci. Tech., 41, 1514-1521, doi:10.1021/es072476p, 2007.

Guo, H., Xu, L., Bougiatioti, A., Cerully, K. M., Capps, S. L., Hite Jr., J. R., Carlton, A. G., Lee, S.-H., Bergin, M. H., Ng, N. L., Nenes, A., and Weber, R. J.: Fine-particle water and $\mathrm{pH}$ in the southeastern United States, Atmos. Chem. Phys., 15, 5211-5228, doi:10.5194/acp-15-5211-2015, 2015.

Hallquist, M., Wenger, J. C., Baltensperger, U., Rudich, Y., Simpson, D., Claeys, M., Dommen, J., Donahue, N. M., George, C., Goldstein, A. H., Hamilton, J. F., Herrmann, H., Hoffmann, T., Iinuma, Y., Jang, M., Jenkin, M. E., Jimenez, J. L., Kiendler-Scharr, A., Maenhaut, W., McFiggans, G., Mentel, Th. F., Monod, A., Prévôt, A. S. H., Seinfeld, J. H., Surratt, J. D., Szmigielski, R., and Wildt, J.: The formation, properties and impact of secondary organic aerosol: current and emerging issues, Atmos. Chem. Phys., 9, 5155-5236, doi:10.5194/acp-9-51552009, 2009.

Hennigan, C. J., Bergin, M. H., Russell, A. G., Nenes, A., and Weber, R. J.: Gas/particle partitioning of water-soluble organic aerosol in Atlanta, Atmos. Chem. Phys., 9, 3613-3628, doi:10.5194/acp-9-3613-2009, 2009.

Hong, J., Häkkinen, S. A. K., Paramonov, M., Äijälä, M., Hakala, J., Nieminen, T., Mikkilä, J., Prisle, N. L., Kulmala, M., Riipinen, I., Bilde, M., Kerminen, V.-M., and Petäjä, T.: Hygroscopicity, $\mathrm{CCN}$ and volatility properties of submicron atmospheric aerosol in a boreal forest environment during the summer of 2010, Atmos. Chem. Phys., 14, 4733-4748, doi:10.5194/acp-144733-2014, 2014.

IPCC (Intergovernmental Panel on Climate Change): Climate Change 2007: The Physical Science Basis, Summary for Policy- 
makers, Cambridge University Press, Cambridge, UK and New York, 2007.

IPCC (Intergovernmental Panel on Climate Change): Climate Change 2013: The Physical Science Basis, Summary for Policymakers, Cambridge University Press, Cambridge, UK and New York, 2013.

Jimenez, J. L., Canagaratna, M. R., Donahue, N. M., Prevot, A. S. H., Zhang, Q., Kroll, J. H., DeCarlo, P. F., Allan, J. D., Coe, H., Ng, N. L., Aiken, A. C., Docherty, K. S., Ulbrich, I. M., Grieshop, A. P., Robinson, A. L., Duplissy, J., Smith, J. D., Wilson, K. R., Lanz, V. A., Hueglin, C., Sun, Y. L., Tian, J., Laaksonen, A., Raatikainen, T., Rautiainen, J., Vaattovaara, P., Ehn, M., Kulmala, M., Tomlinson, J. M., Collins, D. R., Cubison, M. J., Dunlea, E. J., Huffman, J. A., Onasch, T. B., Alfarra, M. R., Williams, P. I., Bower, K., Kondo, Y., Schneider, J., Drewnick, F., Borrmann, S., Weimer, S., Demerjian, K., Salcedo, D., Cottrell, L., Griffin, R., Takami, A., Miyoshi, T., Hatakeyama, S., Shimono, A., Sun, J. Y., Zhang, Y. M., Dzepina, K., Kimmel, J. R., Sueper, D., Jayne, J. T., Herndon, S. C., Trimborn, A. M., Williams, L. R., Wood, E. C., Middlebrook, A. M., Kolb, C. E., Baltensperger, U., and Worsnop, D. R.: Evolution of organic aerosols in the atmosphere, Science, 326, 1525-1529, doi:10.1126/science.1180353, 2009.

Kalberer, M., Paulsen, D., Sax, M., Steinbacher, M., Dommen, J., Prevot, A. S. H., Fisseha, R., Weingartner, E., Frankevich, V., Zenobi, R., and Baltensperger, U.: Identification of polymers as major components of atmospheric organic aerosols, Science, 303, 1659-1662, doi:10.1126/science.1092185, 2004.

Kanakidou, M., Seinfeld, J. H., Pandis, S. N., Barnes, I., Dentener, F. J., Facchini, M. C., Van Dingenen, R., Ervens, B., Nenes, A., Nielsen, C. J., Swietlicki, E., Putaud, J. P., Balkanski, Y., Fuzzi, S., Horth, J., Moortgat, G. K., Winterhalter, R., Myhre, C. E. L., Tsigaridis, K., Vignati, E., Stephanou, E. G., and Wilson, J.: Organic aerosol and global climate modelling: a review, Atmos. Chem. Phys., 5, 1053-1123, doi:10.5194/acp-5-1053-2005, 2005.

Köhler, H.: The nucleus in the growth of hygroscopic droplets, T. Faraday Soc., 32, 1152-1161, 1936.

Kroll, J. H. and Seinfeld, J. H.: Chemistry of secondary organic aerosol: formation and evolution of low-volatility organic in the atmosphere, Atmos. Environ., 42, 3593-3624, doi:10.1016/j.atmosenv.2008.01.003, 2008.

Kroll, J. H., Smith, J. D., Che, D. L., Kessler, S. H., Worsnop, D. R., and Wilson, K. R.: Measurement of fragmentation and functionalization pathways in the heterogeneous oxidation of oxidized organic aerosol, Phys. Chem. Chem. Phys., 11, 8005-8014, doi:10.1039/B905289E, 2009.

Kroll, J. H., Donahue, N. M., Jimenez, J. L., Kessler, S. H., Canagaratna, M. R., Wilson, K. R., Altieri, K., E., Mazzoleni, L. R., Wozniak, A. S., Bluhm, H., Mysak, E. R., Smith, J. D., Kolb, C. E., and Worsnop, D. R.: Carbon oxidation state as a metric for describing the chemistry of atmospheric organic aerosol, Nature Chemistry, 3, 133-139, doi:10.1038/nchem.948, 2011.

Kuwata, M., Kondo, Y., Mochida, M., Takegawa, N., and Kawamura, K.: Dependence of CCN activity of less volatile particles on the amount of coating observed in Tokyo, J. Geophys. Res., 112, D11207, doi:10.1029/2006JD007758, 2007.

Lambe, A. T., Onasch, T. B., Massoli, P., Croasdale, D. R., Wright, J. P., Ahern, A. T., Williams, L. R., Worsnop, D. R., Brune, W. H., and Davidovits, P.: Laboratory studies of the chemical composition and cloud condensation nuclei $(\mathrm{CCN})$ activity of secondary organic aerosol (SOA) and oxidized primary organic aerosol (OPOA), Atmos. Chem. Phys., 11, 8913-8928, doi:10.5194/acp11-8913-2011, 2011.

Lance, S., Medina, J., Smith, J. N., and Nenes, A.: Mapping the operation of the DMT continuous flow CCN counter, Aerosol Sci. Tech., 40, 242-254, doi:10.1080/02786820500543290, 2006.

Lanz, V. A., Alfarra, M. R., Baltensperger, U., Buchmann, B., Hueglin, C., and Prévôt, A. S. H.: Source apportionment of submicron organic aerosols at an urban site by factor analytical modelling of aerosol mass spectra, Atmos. Chem. Phys., 7, 15031522, doi:10.5194/acp-7-1503-2007, 2007.

Lathem, T. L. and Nenes, A.: Water vapor depletion in the DMT continuous flow CCN chamber: effects on supersaturation and droplet growth, Aerosol Sci. Tech., 45, 604-615, doi:10.1080/02786826.2010.551146, 2011.

Lathem, T. L., Beyersdorf, A. J., Thornhill, K. L., Winstead, E. L., Cubison, M. J., Hecobian, A., Jimenez, J. L., Weber, R. J., Anderson, B. E., and Nenes, A.: Analysis of CCN activity of Arctic aerosol and Canadian biomass burning during summer 2008, Atmos. Chem. Phys., 13, 2735-2756, doi:10.5194/acp-13-27352013, 2013.

Li, Y.-H., Zhang, Z., Docherty, K. S., Zhang, H., Budisulistiorini, S. H., Rubitschun, C. L., Shaw, S. L., Knipping, E. M., Edgerton, E. S., Kleindienst, T. E., Gold, A., and Surratt, J. D.: Isoprene epoxydiols as precursors to secondary organic aerosol formation: acid-catalyzed reactive uptake studies with authentic compounds, Environ. Sci. Technol., 46, 250-258, doi:10.1021/es202554c, 2012.

Li, Z., Schwier, A. N., Sareen, N., and McNeill, V. F.: Reactive processing of formaldehyde and acetaldehyde in aqueous aerosol mimics: surface tension depression and secondary organic products, Atmos. Chem. Phys., 11, 11617-11629, doi:10.5194/acp11-11617-2011, 2011.

Massoli, P., Lambe, A. T., Ahern, A. T., Williams, L. R., Ehn, M., Mikkilä, J., Canagaratna, M. R., Brune, W. H., Onasch, T. B., Jayne, J. T., Petäjä, T., Kulmala, M., Laaksonen, A., Kolb, C. E., Davidovits, P., and Worsnop, D. R.: Relationship between aerosol oxidation level and hygroscopic properties of laboratory generated secondary organic aerosol (SOA) particles, Geophys. Res. Lett., 37, L24801, doi:10.1029/2010GL045258, 2010.

Meyer, N. K., Duplissy, J., Gysel, M., Metzger, A., Dommen, J., Weingartner, E., Alfarra, M. R., Prevot, A. S. H., Fletcher, C., Good, N., McFiggans, G., Jonsson, Å. M., Hallquist, M., Baltensperger, U., and Ristovski, Z. D.: Analysis of the hygroscopic and volatile properties of ammonium sulphate seeded and unseeded SOA particles, Atmos. Chem. Phys., 9, 721-732, doi:10.5194/acp-9-721-2009, 2009.

Moore, R. H. and Nenes, A.: Scanning flow CCN analysis a method for fast measurements of CCN spectra, Aerosol Sci Tech., 43, 1192-1207, doi:10.1080/02786820903289780, 2009.

Moore, R. H., Bahreini, R., Brock, C. A., Froyd, K. D., Cozic, J., Holloway, J. S., Middlebrook, A. M., Murphy, D. M., and Nenes, A.: Hygroscopicity and composition of Alaskan Arctic CCN during April 2008, Atmos. Chem. Phys., 11, 11807-11825, doi:10.5194/acp-11-11807-2011, 2011.

Nenes, A., Pandis, S. N., and Pilinis, C.: ISORROPIA: a new thermodynamic model for multiphase multicom- 
ponent inorganic aerosols, Aquat. Geochem., 4, 123-152, doi:10.1023/A:1009604003981, 1998.

Ng, N. L., Canagaratna, M. R., Zhang, Q., Jimenez, J. L., Tian, J., Ulbrich, I. M., Kroll, J. H., Docherty, K. S., Chhabra, P. S., Bahreini, R., Murphy, S. M., Seinfeld, J. H., Hildebrandt, L., Donahue, N. M., DeCarlo, P. F., Lanz, V. A., Prévôt, A. S. H., Dinar, E., Rudich, Y., and Worsnop, D. R.: Organic aerosol components observed in Northern Hemispheric datasets from Aerosol Mass Spectrometry, Atmos. Chem. Phys., 10, 46254641, doi:10.5194/acp-10-4625-2010, 2010.

Nguyen, T. B., Coggon, M. M., Bates, K. H., Zhang, X., Schwantes, R. H., Schilling, K. A., Loza, C. L., Flagan, R. C., Wennberg, P. O., and Seinfeld, J. H.: Organic aerosol formation from the reactive uptake of isoprene epoxydiols (IEPOX) onto nonacidified inorganic seeds, Atmos. Chem. Phys., 14, 3497-3510, doi:10.5194/acp-14-3497-2014, 2014

Ohata, S., Moteki, N., and Kondo, Y.: Evaluation of a method for meaurement of the concentration and size distribution of black carbon particles suspended in rainwater, Aerosol Sci. Tech., 45, 1326-1336, 2011.

Orsini, D. A., Ma, Y., Sullivan, A., Sierau, B., Baumann, K., and Weber, R.: Refinements to the Particle-Into-Liquid Sampler (PILS) for ground and airborne measurements of water soluble aerosol composition, Atmos. Environ., 37, 1243-1259, 2003.

Padró, L. T., Tkacik, D., Lathem, T., Hennigan, C., Sullivan, A. P., Weber, R. J., Huey, L. G., and Nenes, A.: Investigation of cloud condensation nuclei properties and droplet growth kinetics of the water-soluble aerosol fraction in Mexico City, J. Geophys. Res., 115, D09204, doi:10.1029/2009JD013195, 2010.

Perry, R. H. and Green, D. W. (Eds.): Physical and chemical data, in: Perry's Chemical Engineers' Handbook, 7th Edn., McGrawHill, New York, 1997.

Petters, M. D. and Kreidenweis, S. M.: A single parameter representation of hygroscopic growth and cloud condensation nucleus activity, Atmos. Chem. Phys., 7, 1961-1971, doi:10.5194/acp-71961-2007, 2007.

Petters, M. D., Wex, H., Carrico, C. M., Hallbauer, E., Massling, A., McMeeking, G. R., Poulain, L., Wu, Z., Kreidenweis, S. M., and Stratmann, F.: Towards closing the gap between hygroscopic growth and activation for secondary organic aerosol - Part 2: theoretical approaches, Atmos. Chem. Phys., 9, 3999-4009, doi:10.5194/acp-9-3999-2009, 2009.

Portmann, R. W., Solomon, S., and Hegerl, G. C.: Spatial and seasonal patterns in climate change, temperatures, and precipitation across the United States, P. Natl. Acad. Sci. USA, 106, 73247329, doi:10.1073/pnas.0808533106, 2009.

Poulain, L., Wu, Z., Petters, M. D., Wex, H., Hallbauer, E., Wehner, B., Massling, A., Kreidenweis, S. M., and Stratmann, F.: Towards closing the gap between hygroscopic growth and $\mathrm{CCN}$ activation for secondary organic aerosols - Part 3: Influence of the chemical composition on the hygroscopic properties and volatile fractions of aerosols, Atmos. Chem. Phys., 10, 37753785, doi:10.5194/acp-10-3775-2010, 2010.

Pye, H. O. T. and Seinfeld, J. H.: A global perspective on aerosol from low-volatility organic compounds, Atmos. Chem. Phys., 10, 4377-4401, doi:10.5194/acp-10-4377-2010, 2010.

Raatikainen, T., Lin, J. J, Cerully, K. M., Lathem, T. L., Moore, R. H., and Nenes, A.: CCN data interpretation under dynamic operation conditions, Aerosol Sci. Tech., 48, 552-561, doi:10.1080/02786826.2014.899429, 2014.

Reynolds, J. C., Last, D. J., McGillen, M., Nijs, A., Horn, A. B., Percival, C., Carpenter, L. J., and Lewis, A. C.: Structural analysis of oligomeric molecules formed from the reaction products of oleic acid ozonolysis, Environ. Sci. Technol., 40, 6674-6681, doi:10.1021/es060942p, 2006.

Ristovski, Z. D., Suni, T., Kulmala, M., Boy, M., Meyer, N. K., Duplissy, J., Turnipseed, A., Morawska, L., and Baltensperger, U.: The role of sulphates and organic vapours in growth of newly formed particles in a eucalypt forest, Atmos. Chem. Phys., 10, 2919-2926, doi:10.5194/acp-10-2919-2010, 2010.

Roberts, G. C. and Nenes, A.: A continuous-flow streamwise thermal-gradient $\mathrm{CCN}$ chamber for atmospheric measurements, Aerosol Sci. Tech., 39, 206-221, doi:10.1080/027868290913988, 2005.

Romakkaniemi, S., Jaatinen, A., Laaksonen, A., Nenes, A., and Raatikainen, T.: Ammonium nitrate evaporation and nitric acid condensation in DMT CCN counters, Atmos. Meas. Tech., 7, 1377-1384, doi:10.5194/amt-7-1377-2014, 2014.

Ruehl, C. R., Chuang, P. Y., and Nenes, A.: Aerosol hygroscopicity at high (99 to $100 \%$ ) relative humidities, Atmos. Chem. Phys., 10, 1329-1344, doi:10.5194/acp-10-1329-2010, 2010.

Saleh, R., Shihadeh, A., and Khlystov, A.: On transport phenomena and equilibration time scales in thermodenuders, Atmos. Meas. Tech., 4, 571-581, doi:10.5194/amt-4-571-2011, 2011.

Sareen, N., Schwier, A. N., Shapiro, E. L., Mitroo, D., and McNeill, V. F.: Secondary organic material formed by methylglyoxal in aqueous aerosol mimics, Atmos. Chem. Phys., 10, 997-1016, doi:10.5194/acp-10-997-2010, 2010.

Sullivan, R. C., Moore, M. J. K., Petters, M. D., Kreidenweis, S. M., Roberts, G. C., and Prather, K. A.: Effect of chemical mixing state on the hygroscopicity and cloud nucleation properties of calcium mineral dust particles, Atmos. Chem. Phys., 9, 33033316, doi:10.5194/acp-9-3303-2009, 2009.

Tritscher, T., Dommen, J., DeCarlo, P. F., Gysel, M., Barmet, P. B., Praplan, A. P., Weingartner, E., Prévôt, A. S. H., Riipinen, I., Donahue, N. M., and Baltensperger, U.: Volatility and hygroscopicity of aging secondary organic aerosol in a smog chamber, Atmos. Chem. Phys., 11, 11477-11496, doi:10.5194/acp-1111477-2011, 2011.

VanReken, T. M., Ng, N. L., Flagan, R. C., and Seinfeld, J. H.: Cloud condensation nucleus activation properties of biogenic secondary organic aerosol, J. Geophys. Res., 110, D07206, doi:10.1029/2004JD005465, 2005.

Varutbangkul, V., Brechtel, F. J., Bahreini, R., Ng, N. L., Keywood, M. D., Kroll, J. H., Flagan, R. C., Seinfeld, J. H., Lee, A., and Goldstein, A. H.: Hygroscopicity of secondary organic aerosols formed by oxidation of cycloalkenes, monoterpenes, sesquiterpenes, and related compounds, Atmos. Chem. Phys., 6, 23672388, doi:10.5194/acp-6-2367-2006, 2006.

Villani, P., Sellegri, K., Monier, M., and Laj, P.: Influence of semivolatile species on particle hygroscopic growth, Atmos. Environ., 79, 129-137, doi:10.1016/j.atmosenv.2013.05.069, 2013.

Wang, S. C. and Flagan, R. C.: Scanning electrical mobility spectrometer, Aerosol Sci. Tech., 13, 230-240, 1990.

Weber, R. J., Orsini, D., Daun, Y., Lee, Y.-N., Klotz, P., and Brechtel, F.: A particle-into-liquid collector for rapid measurements of 
aerosol chemical composition, Aerosol Sci. Tech., 35, 718-727, doi:10.1080/02786820152546761, 2001.

Wex, H., Petters, M. D., Carrico, C. M., Hallbauer, E., Massling, A., McMeeking, G. R., Poulain, L., Wu, Z., Kreidenweis, S. M., and Stratmann, F.: Towards closing the gap between hygroscopic growth and activation for secondary organic aerosol: Part $1-$ Evidence from measurements, Atmos. Chem. Phys., 9, 3987-3997, doi:10.5194/acp-9-3987-2009, 2009.

Xu, L., Guo, H., Boyd, C. M., Klein, M., Bougiatioti, A., Cerully, K. M., Hite, J. R., Isaacman-VanWerts, G., Kreisberg, N. M., Knote, C., Olson, K., Koss, A., Goldstein, A. H., Hering, S. V., de Gouw, J., Baumann, K., Lee, S.-H., Nenes, A., Weber, R. J., and $\mathrm{Ng}$, N. L.: Effects of anthropogenic emissions on aerosol formation from isoprene and monoterpenes in the Southeastern United States, P. Natl. Acad. Sci. USA, 112, 37-42, doi:10.1073/pnas.1417609112, 2015.
Xu, L., Kollman, M. S., Song, C., Shilling, J. E., and Ng, N. L.: Effects of $\mathrm{NO}_{x}$ on the volatility of secondary organic aerosol from isoprene photooxidation, Environ. Sci. Technol., 48, 22532263, doi:10.1021/es404842g, 2014.

Zuend, A. and Seinfeld, J. H.: Modeling the gas-particle partitioning of secondary organic aerosol: the importance of liquidliquid phase separation, Atmos. Chem. Phys., 12, 3857-3882, doi:10.5194/acp-12-3857-2012, 2012. 